\title{
Cindy Sherman'ın Fotoğraflarında Gerçeklik Algısı
}

\author{
Emel Erkan Güray*
}

Kocaeli Üniversitesi, Sosyal Bilimler Enstitüsü, Plastik Sanatlar Ana Sanat Dall, Kocaeli

\begin{abstract}
Öz
Postmodern dönemde gerçeklik algısı fotoğraf tekniğinin yarattı̆̆ olanaklarla birlikte oyunsal bir sürece girmiştir. Bu oyunsal süreç alıntılama ve kendine mal etme (pastiş) yöntemi ile sanat olgusunun gerçeklï̆ini yerinden etmeye çalısır. Fotoğraf tekniğini bir yeniden kurgulama ve üretme aracı olarak kullanan sanatçı Cindy Sherman'ın fotoğraflarının incelenmesini amaçlayan bu yazıda, sanatçının kendi varoluşsal gerçekliği, kimliklerin ve mekanların kendine mal ederek yeniden kurgulanması gibi konular üzerinde durulacaktır.
\end{abstract}

Anahtar Kelimeler: Sanat, Fotoğraf, Gerçeklik, Jean Baudrillard, Cindy Sherman

\section{Perception of Reality on Cindy Sherman's Photographs}

\section{Abstract}

Perception of reality is in a playfull process with the possibilities that created by the techniques of photography. This playfull process tries to displace the essence and reality of art phenomenon. This article aims to examine the photographs of artist Cindy Sherman, who uses photography as a means of reconstruction and production, and will focus on the artist's own existential reality, the reconstruction of identities and spaces.

Keywords: Art, Photography, Reality, Jean Baudrillard, Cindy Sherman

\section{Giriş}

Postmodern dönemde sanatçı kendini ifade etme konusunda sonsuz seçeneğe sahiptir ve bu çeşitlenme karşısında var olan biçimleri yeniden ele almayı tercih eder. Yöntem olarak ise kendine mal etme ya da pastiş ${ }^{1}$, sıkça kullanılmaktadır. Postmodern dönemin özelliklerinden biri olan bu yeniden yorumlama ve alıntılama durumu Steven Best ve Douglas Kellner' in "Postmodern Teori" adlı çalışmalarında da belirttikleri gibi: "Modernist ciddiyet, sofuluk ve bireysellik değerlerine karşı postmodern sanat yeni bir lakaytlık, yeni bir oyunculluk ve yeni bir eklektisizm sergiler." (Best, Kellner, 2011: 26) şeklinde tanımlanabilir. Farklı düşünsel ve sanatsal alanlara ait özelliklerin yeni bir oluşumda bir araya getirilmesi olarak ifade edilebilecek eklektisizm mantığına göre, sanatçı özgün olma kaygısını bir tarafa bırakarak ortaya yeni bir şey çıkarmak yerine alıntılara başvurabilir. Alıntılanan unsurların birbiri ile ilgili olması gerekmediği için ortaya parçalı ve birbirinden bağımsız biçimler çıkar. Buna göre Modernizmin katı bir şekilde sebep-sonuç ilişkilerinin kesin çizgilerle belirtildiği tanımlamalarına karşılık,

1Pastiş: Çeşitli eserlerden alınan parçaların, bir bütün içinde eritilmeden veya özgün bir çalışma oluşturmadan, bir yapıt oluşturmak amacıyla bir araya getirilmesi. Kaynak: Sanatta İroni ve Öyküleme Pratikleri, Özlem Tekdemir Dökeroğlu, Hacettepe Üniversitesi Güzel Sanatlar Enstitüsü Sanatta Yeterlik Eser Çalışması Raporu, Ankara, 2013.

*Yazışma adresi. Email: emelerkann@gmail.com 
Postmodernizmde birçok kavramin yerinden edilerek tekrar ele alındı̆̆ görülmektedir. Buradan hareketle kavramların ve öznelerin sabit olamayacağ1 düşüncesini vurgulayan dönemin düşünürlerinden Jacques Lacan'ın da belirttiği gibi "Ĕ̆er bir gösterenin anlamı "sabit" olsaydı, gösteren ve gösterilen arasındaki ilişki değişmeyen tek bir anlam yaratırdı. Ancak böyle bir ilişki yoktur, bu nedenle gösterenler zincirinde sürekli bir kayma, akış ve dolaşım vardır. Gösterenler devamlı olarak diğer gösterenlerle olan ilişkilerinde kendilerini var ederler, sürekli, sabit olmayan akışkan ilişki söz konusudur." (Rigel, Batuş, Yücedoğan, Çoban, 2005:280) Lacan'a göre gerçeklik simgelerin yani kavramların arkasında aranmalıdır, çünkü katı tanımlamalar ve belirlenmişlikler bir kavramı kendi özünden uzaklaştırarak eleştiriye ve değişime kapalı hale getirir. Bu Modernist tutum Postmodern dönemin ruhuna aykırı olacaktır. Böyle bir durumda Postmodern dönemin gerçeklik algısının hangi koşullar altında şekilleneceği önem kazanmaktadir.

Postmodern gerçeklik algısının kaygan bir zeminde yapılanmaya başlayarak nesnellikten sanallığa yani hipergerçeklik ${ }^{2}$ aşamasına geçtiğini savunan Fransız düşünür Jean Baudrillard'a göre gerçek ve kopya arasında hiçbir fark kalmamıştır. Buna göre çoğu zaman gerçeğin kendisinden çok temsili önemsenmeye başlanır ve gelip geçici görünümlerle dolu bir imaj karmaşası içine çekiliriz. Bu imajlar tekrarlar halinde karşımıza çıkarıldığı için bir süre sonra hayatlarımızın parçası haline gelmeye başlamıştır. Baudrillard birbirini tekrar eden sayısız görüntülerle kurgulanmış bir gerçekliğin içinde olduğumuzu ifade eder. "Her yerde mesafeler birbirine karışıyor, her yerde mesafe ortadan kaldirllyyor: Cinsiyetler arasinda, zıt kutuplar arasinda, sahneyle salon arasında, eylemin başkahramanları arasında, özneyle nesne arasında, gerçekle gerçeğin sureti arasında bir mesafe yok artık." (Baudrillard, 2004: 119) Böylece çoklu kimlikler ve çok anlamlılık gibi tanımlamalar ortaya çıkmaktadır. Bu çoğul bakış açısı sanata da yansımış ve ortaya belli bir sanatsal tarzı benimseyen sanatçı algısı yerine birden fazla tarzı birleştiren ve ihtiyacına göre arasından seçim yapan bir sanatçı algısı çıkmıştır. En önemli gelişmelerden biri ise sıradanlığın ve gündelik yaşamın sanat ile iç içe geçmiş olmasıdır. Baudrillard'ın da belirttiği gibi: "Sanat dünyası garip bir görünüm sunuyor. Sanatta ve esinde bir tıkanma var gibi. Birkaç yüzyıl boyunca göz kamaştırıcı biçimde gelişmiş olan şeyler sanki kendi görüntü ve zenginlikleri karşısında taş kesilip aniden donup kalmışlar. Çă̆daş sanatın tüm sarsıntılı deviniminin ardında bir tür durgunluk, artık kendini aşamayan ve giderek daha fazla tekrarlayarak, kendi üstüne kapanan bir şey var. Bir yanda güncel sanat biçimlerinde bir tıkanma ve diğer yanda hızla çoğalma, vahşi bir abartı, geçmiş biçimler üzerine sayısız çeşitleme (ölmüş olanın kendi içinde hareketli yaşamı) var." (Baudrillard, 2004: 21-22) Bu şekilde oluşmaya başlayan sanat ortamında çoğulluk, yeniden kurgulanabilirlik ve gerçeği kendine mal ederek dönüştürme konusunda fotoğraf tekniğinin öne çıktığ1 görülmektedir. Baudrillard'ın bu görüşleri bir eleştiri niteliği taşısa da Postmodern sanatçıların durumu kanıksadığı, hatta Cindy Sherman örneğinde olduğu gibi kendi lehine bile kullandı̆̆ı söylenebilir.

${ }^{2}$ Hipergerçek: Bir köken ya da bir gerçeklikten yoksun gerçeğin modeller aracılığıyla türetilmesine hipergerçek yani simülasyon denilmektedir. Kaynak: Simülakrlar ve Simülasyon (O. Adanır Çev.). Jean Baudrillard Ankara: Doğu Batı Yayınları. 2008 
Cindy Sherman ve onun gibi fotoğrafı sanatının ana malzemesi haline getiren günümüz sanatçılarının çoğu, fotoğraf tekniğinin estetik boyutunun yanı sıra sosyal gerçeklikler üzerindeki etkisinin de ne gibi kullanımları olduğu üzerine sayısız deneyler yapmışlardır. Sherman'ın kullandığı yöntemler başka sanatçılar tarafından da denenmiş, hatta Japon sanatçı Yasumasa Morimura, Sherman'ın 1981 yılında gerçekleştirdiği fotoğraf çalışmasını (Fotoğraf 8) birebir tekrar canlandırmıştır. (Fotoğraf 1) Sanatçının sanat eseri içindeki konumlanışı üzerine sorgulamaların yapılabileceği bu türden çalışmalarda sanatçının kişisel geçmişi ile ilgili ilişkilendirmeler de gözlenebilmektedir. Yasumasa Morimura'nın kadın karakterleri canlandırıyor olması fakat gerçekte cinsiyetinin erkek oluşu dikkat çekici bir noktadır. Aynı zamanda Japon bir sanatçı olması Doğu- Batı kültürü karşılaştırmasını akla getirmektedir. Morimura'nın sanatsal tavrı Batı sanatının görme biçimlerine ve kültürel formlarına eleştirel bir bakış olarak düşünülebilir.

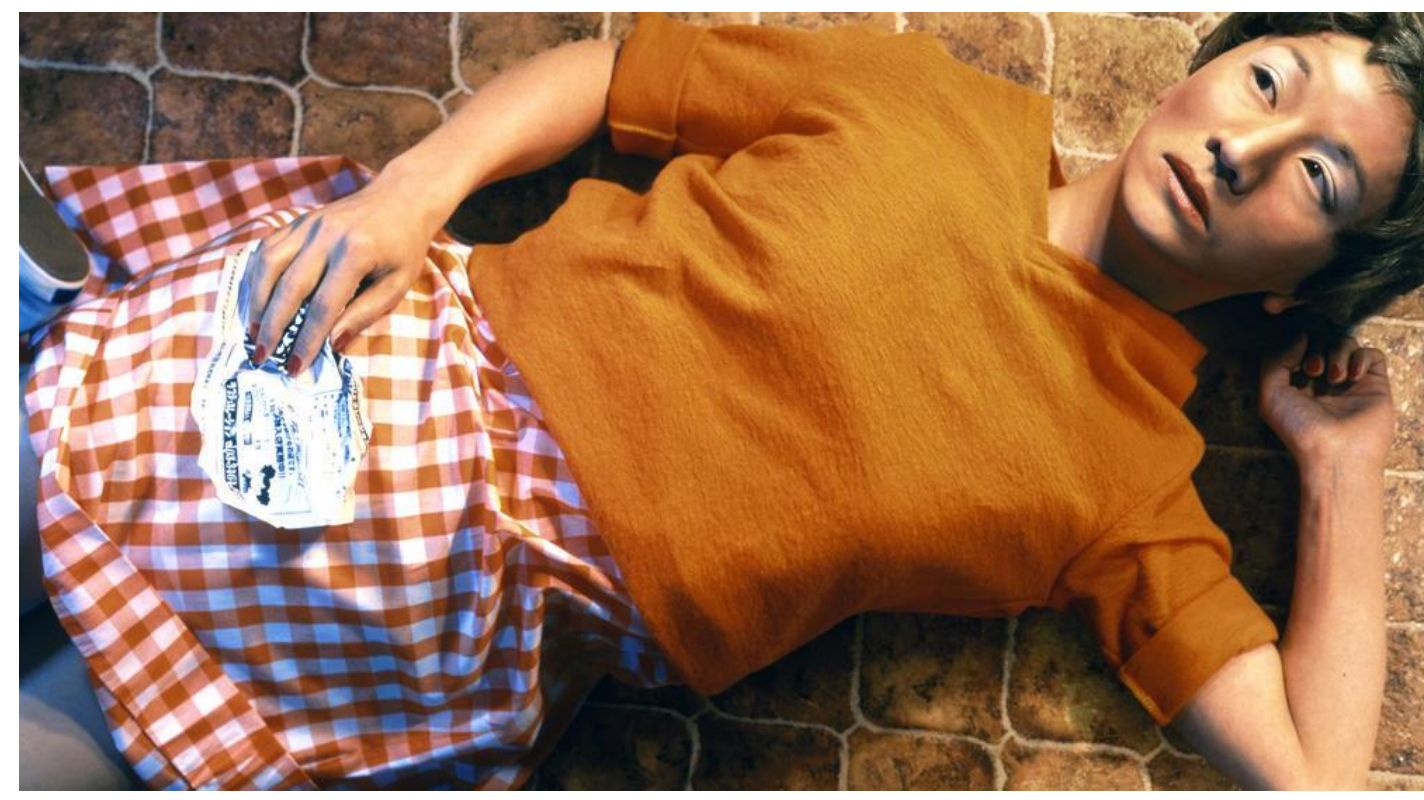

Fotoğraf 1. Yasumasa Morimura, To My Little Sister: for Cindy Sherman, 1998

Benzer bir durum Polonyalı sanatçı Katarzyna Kozyra'nın çalışmalarında da görülmektedir. Sanatçı 1996 yılında gerçekleştirdiği Olympia adlı çalışmasında, bir güzellik temsili olarak görülen Edouard Manet'in 1863 yılında gerçekleştirdiği Olympia imgesine karşılık anti estetik bir tavırla konumlandırdığı kendi bedenini kullanmıştır. (Fotoğraf 2) Sanatçının kanser hastalığına yakalandığı döneme ait olan bu çalışma idealize edilmiş kadın figürünün ardında yatan gerçekliğe, daha doğrusu gündelik yaşamın olağan ve gizlenmemiş olan gerçekliğine dikkat çekmektedir. 


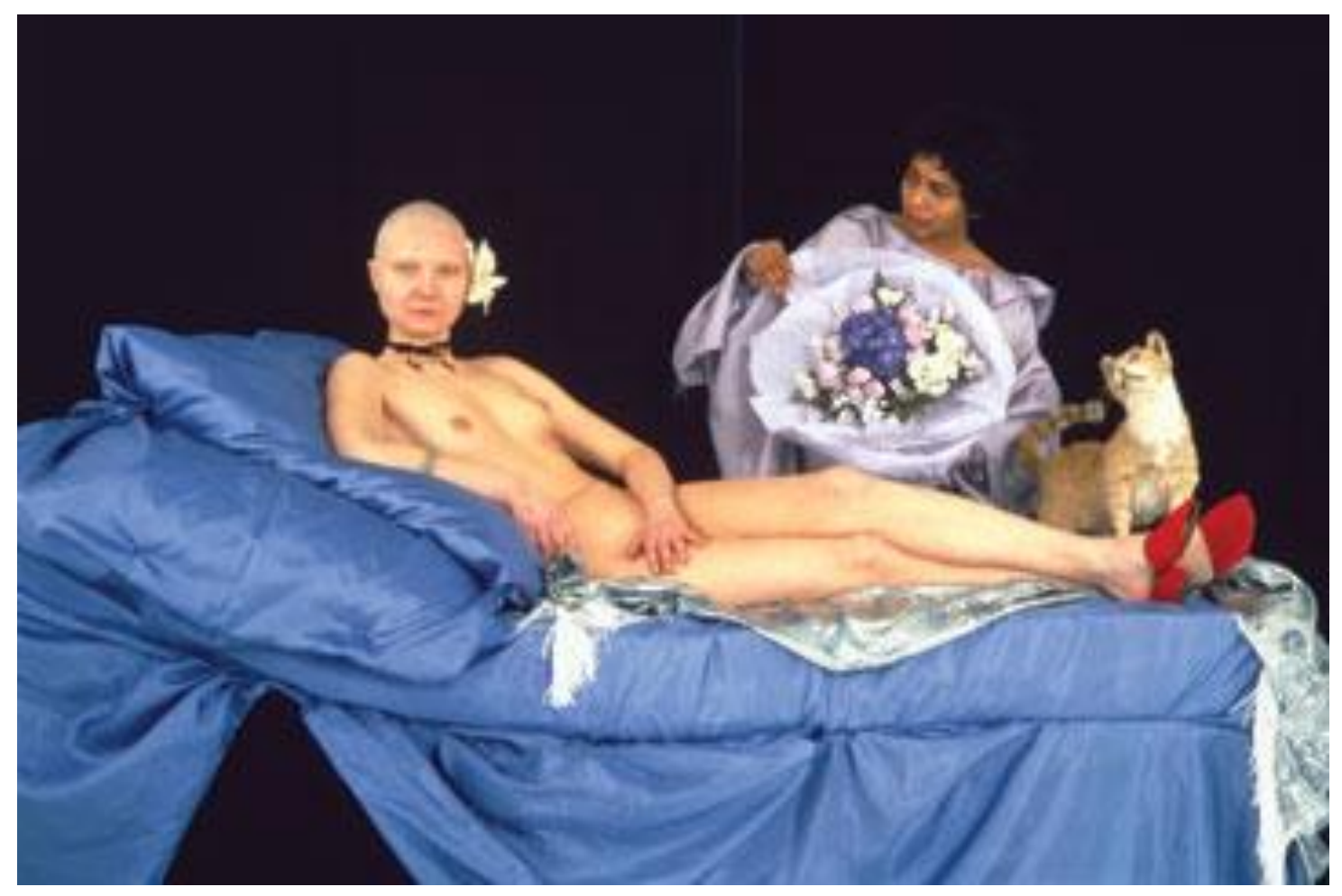

Fotoğraf 2. Katarzyna Kozyra, Olympia, 1996

\section{Cindy Sherman'ın Fotoğraflanında Gerçeklik Algısı}

Fotoğraf tekniği gerçekliği olduğu gibi yansıtmasıyla ortaya çıktığı dönem olan 19.YY ve sonrası için insanlık adına bir dönüm noktasıdır. Önceleri daha çok olayları ve durumları belgeleme ve ölümsüz kılma gibi amaçlara hizmet eden fotoğraf, sanatçıların ilgi alanına girmesiyle birlikte resim sanatına karşılık yeni bir alternatif olmuştur. Walter Benjamin'in 1935-36 yıllarında yazdığı “Tekniğin Olanaklarıyla Yeniden Üretilebildiği Çağda Sanat Yapıtı" adlı yazısında ise sanat eserinin kopyalanması ve teknik imkanlar dahilinde yeniden üretilmesi gibi konuların tartışılmasıyla birlikte, özellikle fotoğrafın sanatsal bir üretim aracı olarak gelecekte ne gibi roller üstlenebileceği üzerine fikir edinebilmek mümkündür. Benjamin'e göre bir sanat eserini eşsiz yapan şey şimdiki zamana ait olmasıdır. Buna göre sanat eseri gerçekliğini şimdiki zamandan alır, ancak örneğin mekanik olarak fotoğraf makinesi aracılığla yeniden üretilen bir sanat yapitı aurasını kaybeder ve bir anlamda dokunulmazlığını da kaybetmiş olur. Bu durum ilk anda olumsuz olarak değerlendirilebilir, fakat fotoğraf kullanımının tarihsel gelişimine bakıldığında günümüz örneklerinden de anlaşılacağı gibi sanatçıların bu alanı çok iyi kullanarak durumu tersine çevirdikleri söylenebilir.

Modernizm boyunca Dada, Fütürizm, Sürrealizm ve Pop Art gibi sanat akımlarında sanatçıların fotoğraftan sıkça faydalandıkları görülür. Fotoğraf tekniği, gerçekliğin kurgulanabilir olabileceğini farkeden sanatçılar için zengin bir deney alanı haline gelmiştir. İhsan Derman'ın da belirttiği gibi: "Artık fotoğrafın da, ressamın fırçasının yarattığı görüntüler gibi, bireysel müdahaleye elverişli bir ortam olduğu görüşü yaygınlık kazanmaya başladı. Mekanik işlemlere dayalı olmasına karşın, bu alanın da, anlatımcı 
ve yaratıcı bir sanat ortamı olduğu anlaşılmaya başlandı." (Derman, 2010: 8) Özellikle fotomontaj ve pozlama tekniğinin geliştirilmesiyle birlikte günümüz fotoğraf anlayışının temelleri atılmıştır.

Postmodern dönemde ortaya çıkan Kavramsal Sanat ve Performans Sanatı gibi sanatsal ifade biçimlerinde fotoğrafın kullanımı hem belgeleme hem de sıradan olanı görünür kılma özellikleri taşımaktadır. Teknolojik gelişmelerin bir sonucu olarak ortaya çıan dijitalleşme ise fotoğrafa bilgisayar ve yazılım programları üzerinden yeni bir görme biçimi kazandırmıştır. Dijital ortamda üretilen fotoğraflarda zaman ve mekân belirsizliği, yapaylık, sonsuz tekrar ve üst üste bindirme gibi özellikler görülmektedir.

Postmodern dönemin gerçeklik algısını tam karşılığıyla kullanan sanatçılardan biri Cindy Sherman'dır. 1954 New Jersey doğumlu sanatçı çalışmalarını New York'taki stüdyosunda sürdürmektedir. Bir sanatçı olarak etrafına karşı geliştirdiği duyarlılıkları kendi var oluşu üzerinden yorumlamaya çalışır. Çalışmalarında ortaya koyduğu çok kimlikli yapıya benzer bir duruşa sahiptir, çünkü aynı zamanda bir model, makyöz, kuaför ve stilisttir. Sahip olduğu bu özellikleri sayesinde çalışmalarını kendi stüdyosunda ve genellikle çok fazla yardım almadan tek başına üretir.

Fotoğraf tekniğiyle oluşturduğu sayısız otoportrelerinde popüler kültür imgelerinden alıntıladığı kimlikleri kendi kimliğiyle birleştirerek parçalanıp tanımlanamaz hale getirir. Böylece öncelikle kendi gerçekliğini, sonra içinde bulunduğu çevrenin gerçekliğini sorgulamaya çalışır. Ahu Antmen'in de dediği gibi: "Sherman, fotoğrafin deyim yerindeyse 'yalan söyleyebilme' potansiyelini ve özelliğini gözler önüne sererken, gösteri kültürünün şekillendirdiği yapay kimliklere göndermede bulunur."(Antmen, 2008: 280) Toplum içinde beliren kimlikleri bazen alaycı bazen de gerçekliklerine uygun şekilde yeniden üretir.

Daha önce de belirtildiği gibi fotoğraf özünde gerçekliği olduğu gibi yansıtan bir özelliğe sahip olduğu için inandırıcilığı oldukça yüksektir. Postmodern fotoğrafın kurgusal gerçeklik anlayışına göre ise sanatçı neye inandırmak istiyorsa onu ön plana çıkarabilir. Cindy Sherman'ın özel makyaj, kostüm, mizansen, sahne ve mekan efektleri sayesinde oluşturduğu karakterleri gerçekten var olmuşçasına canlı ve o ana ait gibidir. 1975-1980 arasında gerçekleştirdiği “İsimsiz Film Kareleri (Untitled Film Stills)" serisinde popüler kültüre mal olmuş kadın figürlerini ve film sahnelerini yeniden canlandırır (Fotoğraf 3, 4, 5, 6). Kurgusal bir gerçeklik olan sinema Sherman'ın fotoğraf karelerinde yeniden kurgulanarak günümüze taşınır. 


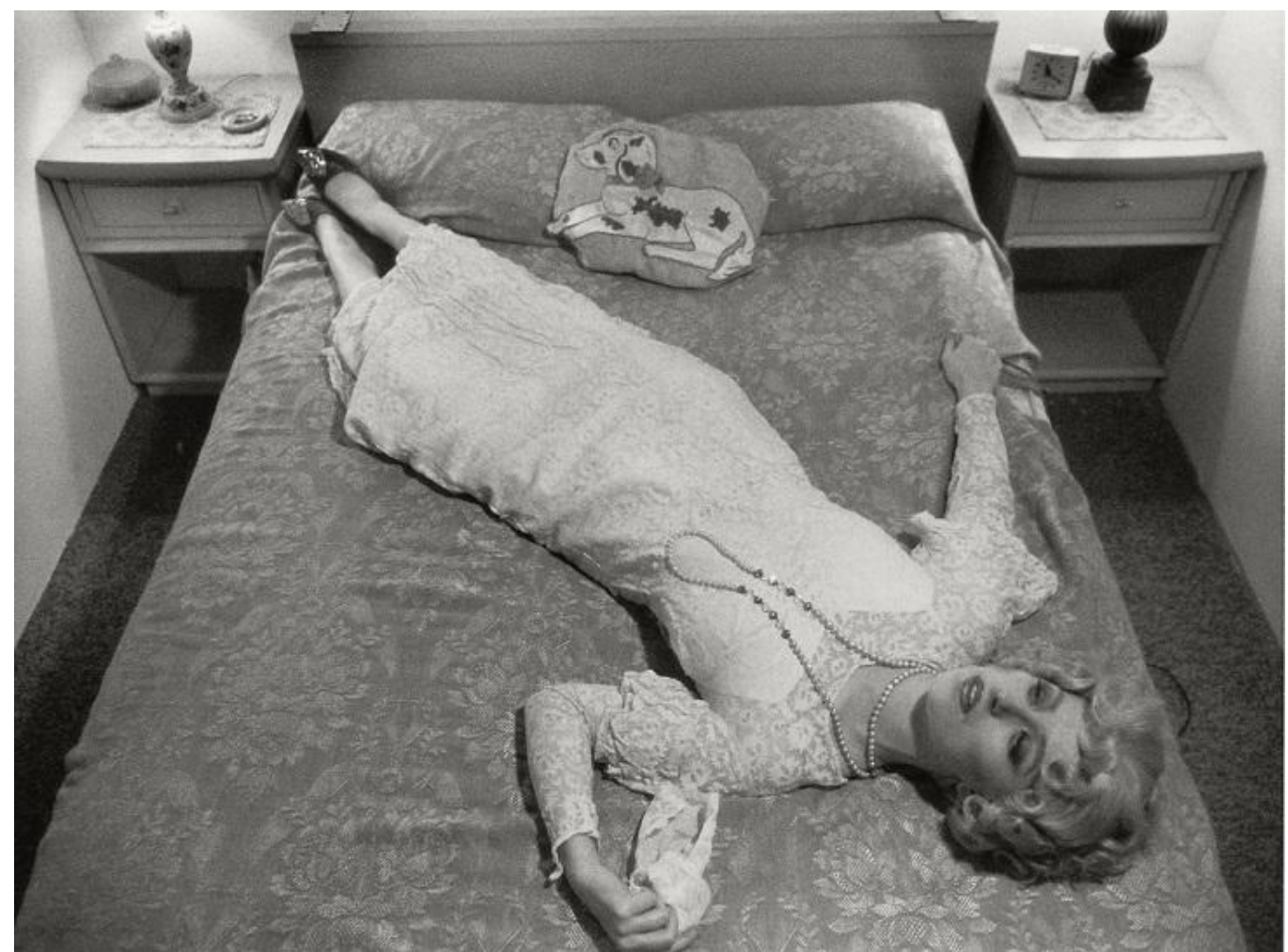

Fotoğraf 3. Cindy Sherman, 'Untitled Film Still No:11', 1978, MOMA(Museum of American Art-Amerikan Modern Sanatlar Müzesi) New York

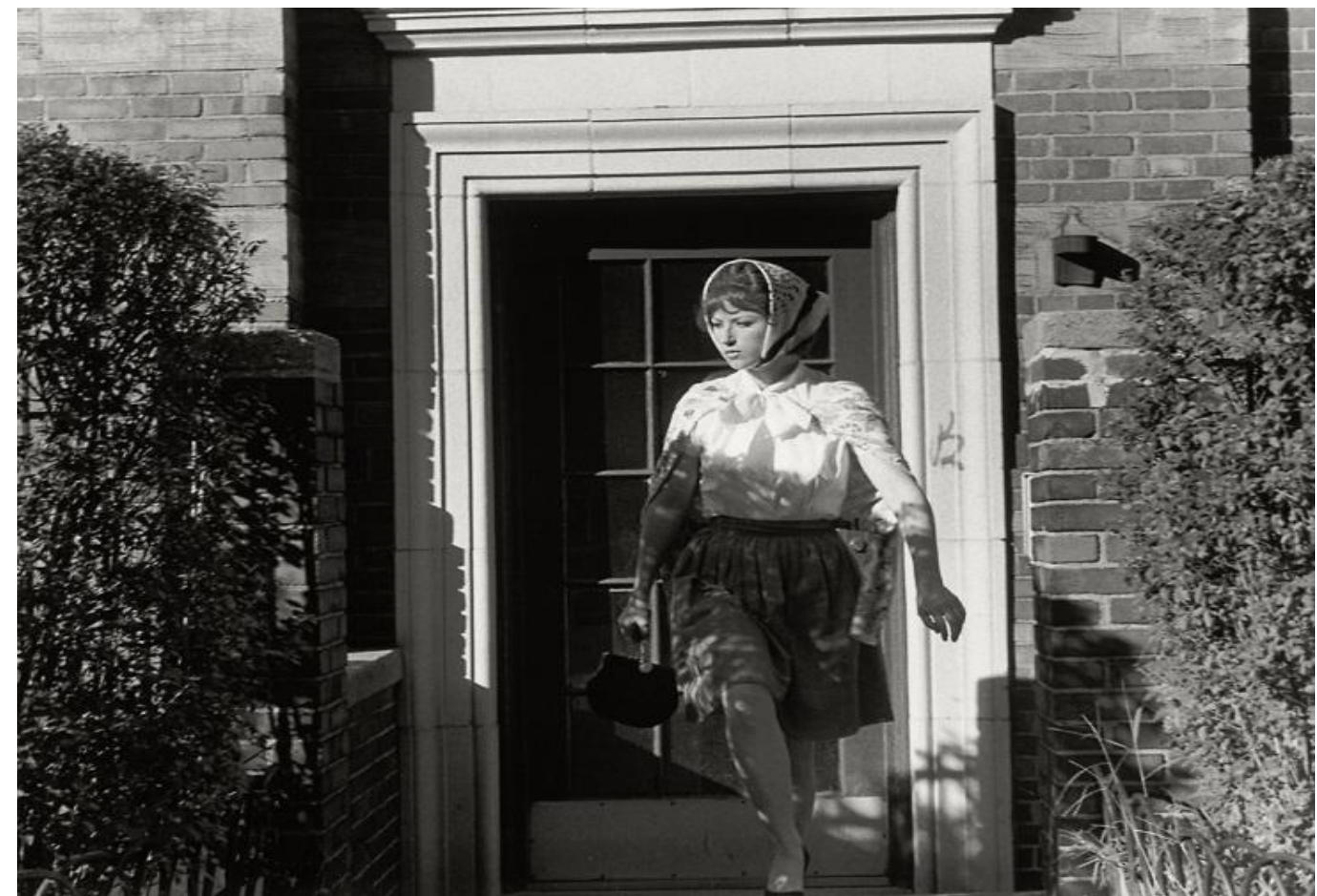

Fotoğraf 4. Cindy Sherman, 'Untitled Film Still No:20', 1978, MOMA

Sherman tüketim toplumu içindeki popüler kültür imgelerini kadın olma durumu üzerinden sorgulamaktadır. Feminist sanat içinde ele alınabilecek kadın 
hakları ve kadının erkek egemen toplumlardaki rolleri gibi bazı sorunsalları kullanarak kadını cinsel bir obje, ev işlerine boğulmuş bir anne ya da şöhretin doruğunda bir star olmuş halde yeniden yorumlar. Kullandığı kadın kimliklerinin çoğunda dramatik bir gerçeklik vardır. Mutsuz ve düşünceli halleriyle bulundukları durumdan memnun değilmiş gibi uzaklara dalarak kaybolup giderler. İçinde bulundukları dönemin yalnızlık ve umutsuzluk dolu gerçekliğiyle yüzleştikleri anlarda yakalanmışlardır objektife.

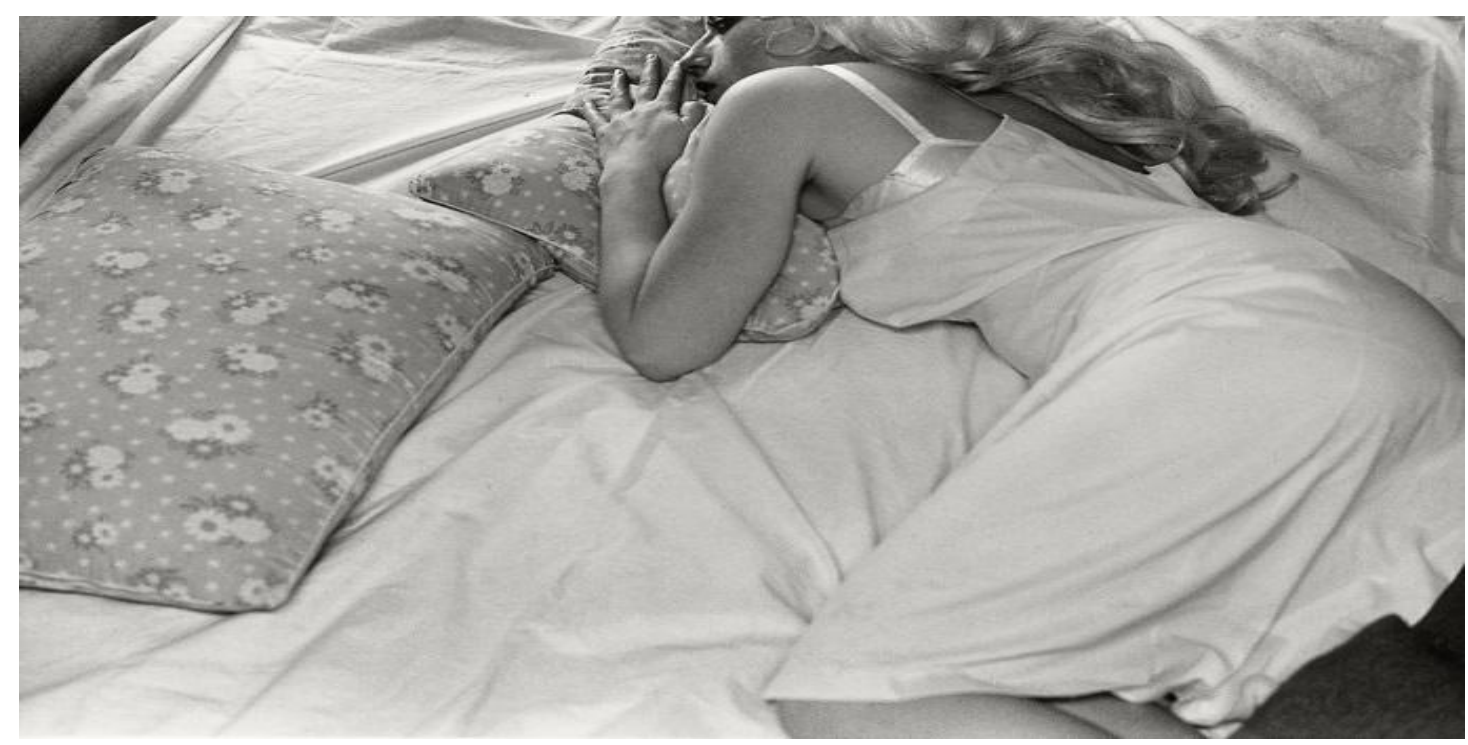

Fotoğraf 5. Cindy Sherman, 'Untitled Film Still No:14', 1978, MOMA

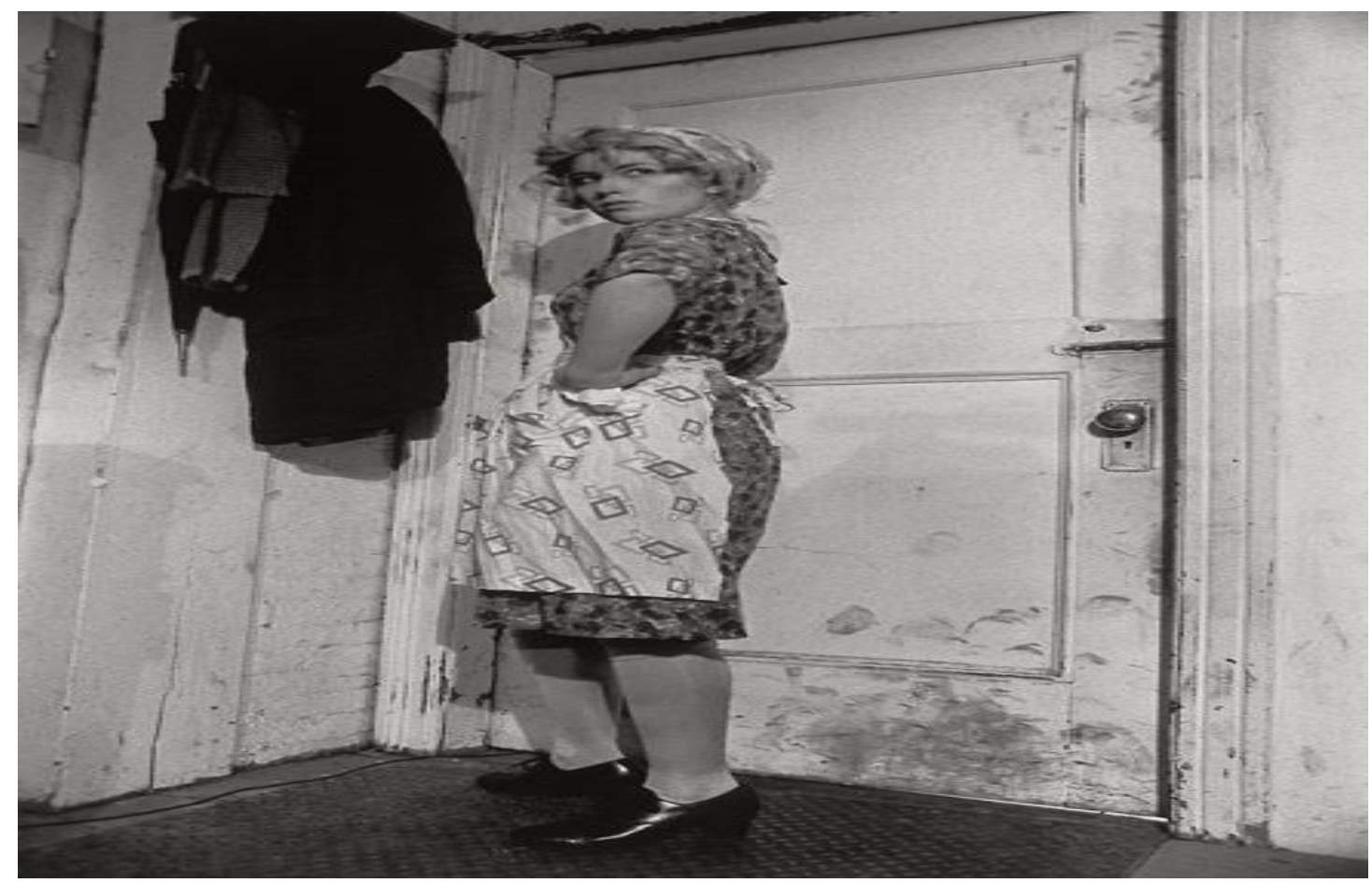

Fotoğraf 6. Cindy Sherman, ‘Untitled Film Still No:35’, 1979, MOMA 
Toplumun kadına yüklemiş olduğu roller yıllar geçtikçe görüntüde değişmiş fakat özünde aynı kalmıştır. 1980 sonrasında kurguladığı kadın kimliklerinde bu ayrım net bir şekilde görülebilir. Olgun görünümlü kadınların yerini daha genç ve ergen kadınlar alır. (Fotoğraf 7,8) Olumsuzluklarla yüzleşme ve toplumun içinde erime yaşı daha da gerilere çekilir. Küçük yaşta ciddi sorunların arasında kendini bulmaya çalışan kimlikler ortaya çıar. Çocukluk ve ergenlik arasında kalmış kimliklerin kendini bulma çabalarının görülebildiği çalışmalarda Sherman, işin içine cinselliği de katar. Cinselliğin tüketim imgesi haline getirilip estetize edilişine dikkat çeker.

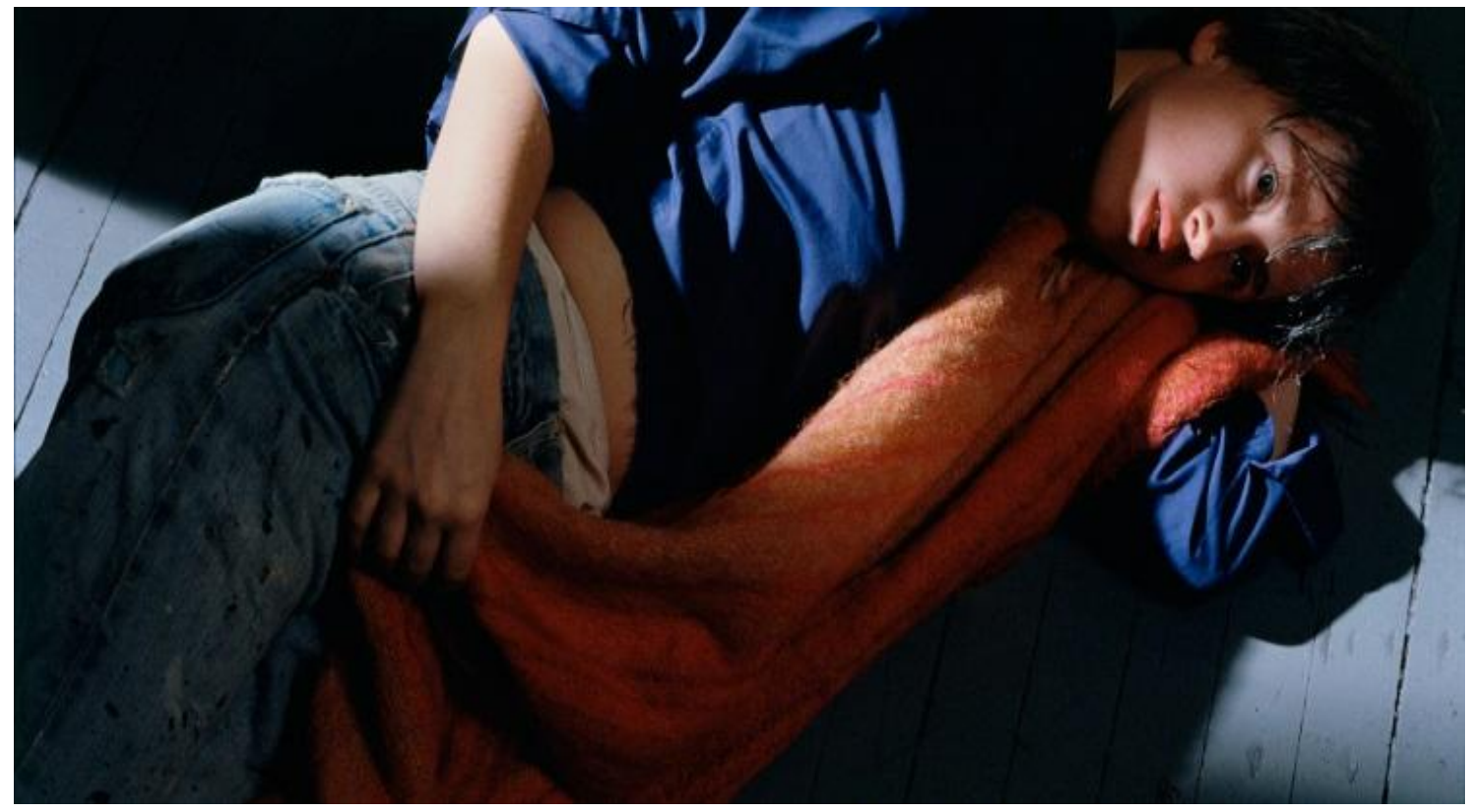

Fotoğraf 7. Cindy Sherman, 'İsimsiz 87', 1981, MOMA

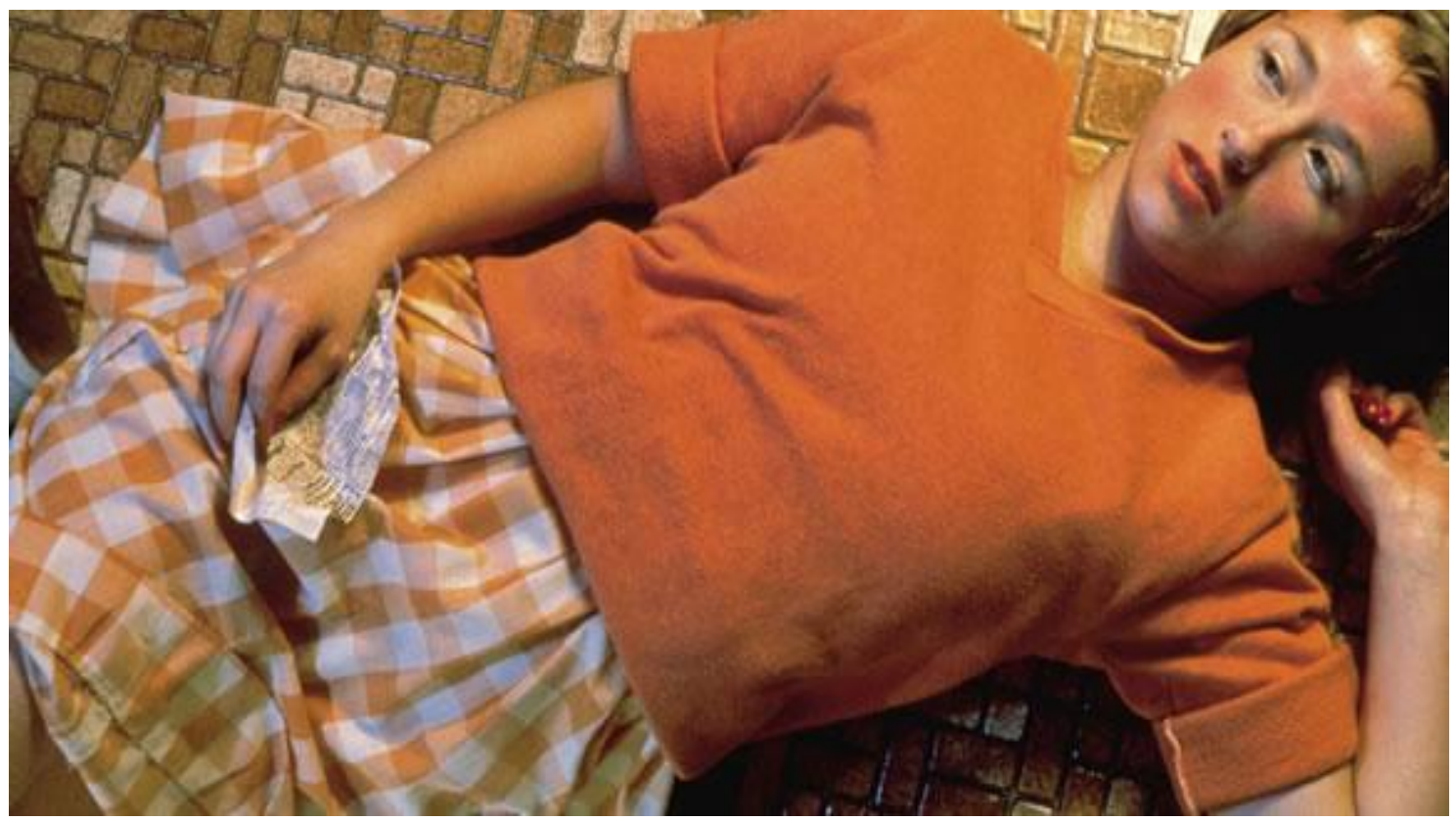

Fotoğraf 8. Cindy Sherman, 'İsimsiz 96', 1981, MOMA 
1985 sonrasında gerçekleştirdiği fotoğraflarda cinselliğin itici uç noktalarında dolaşan sanatçı yapay beden parçaları kullanır. (Fotoğraf 9, 10) Cinsel uzuvları olabildiğince nesneleştirerek, tüketim olgusuna hizmet eder hale getirir. Rahatsız edici bir gerçeklik algısının hakim olduğu bu çalışmalarda artık kimliklerin anlaşılırlığı kalmamıştır.

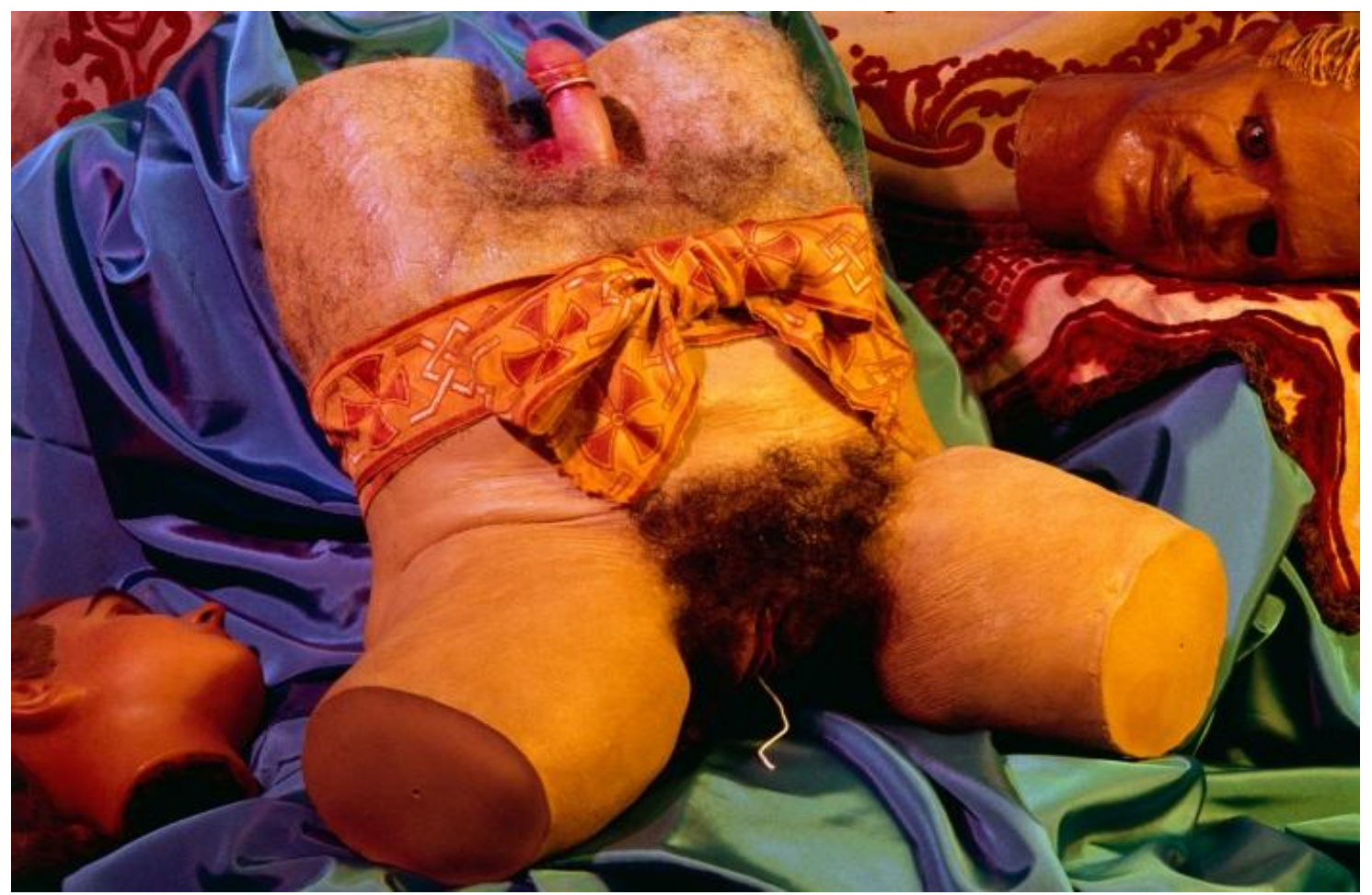

Fotoğraf 9. Cindy Sherman, 'İsimsiz 262', 1992, MOMA

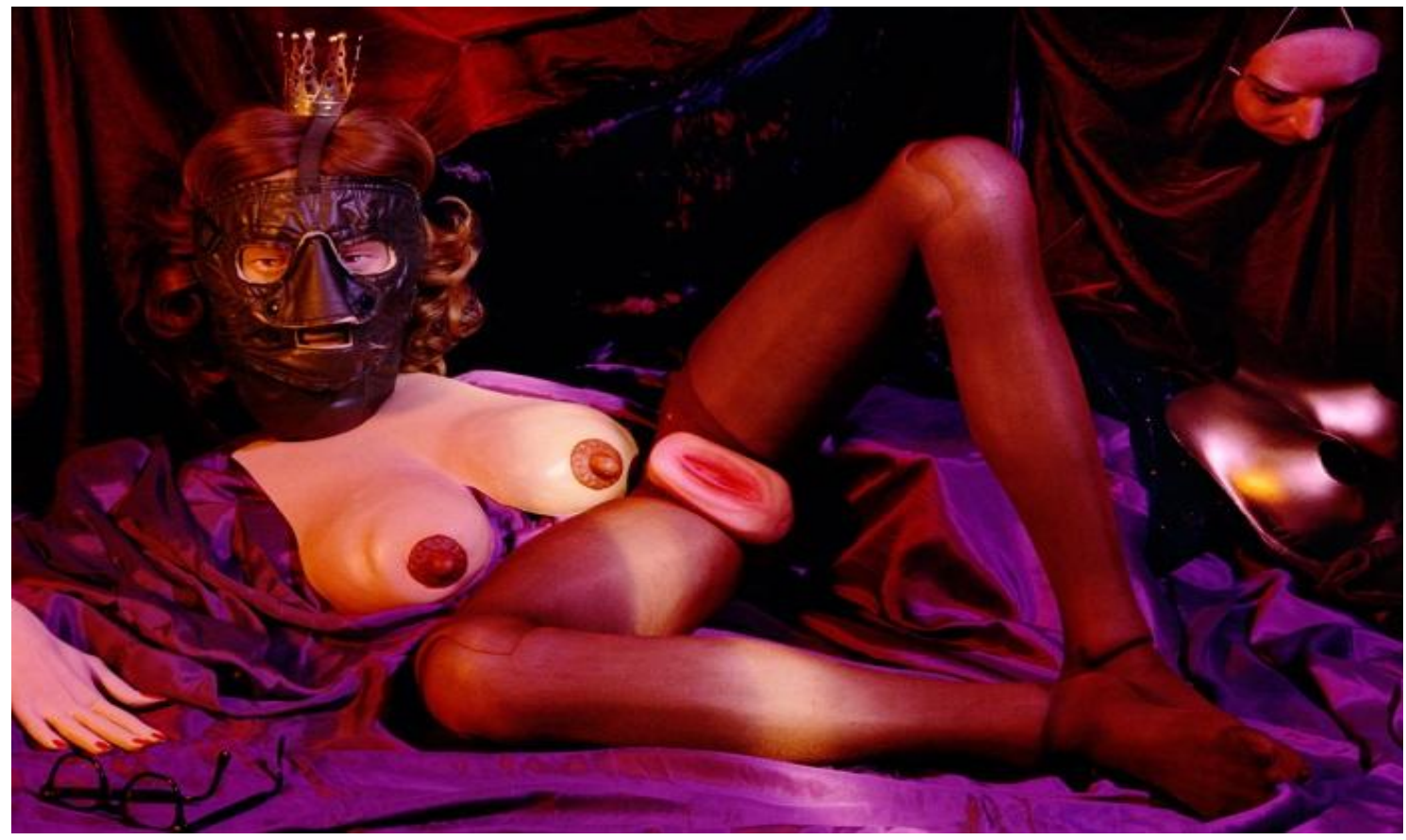

Fotoğraf 10. Cindy Sherman, 'İsimsiz 264’, 1992, MOMA 
Sanatçının beden parçalarını kullandı̆̆ı çalışmalarının çıkış noktası Sürrealist sanatçı Hans Bellmer'dir. Bellmer Sürrealizm'in gerçekliği algılayış biçimine göre kurguladığı oyuncak bebeklerle tanımsız figürler ortaya çıkarır. (Fotoğraf 11, 13) Kendine mal etme yöntemi ile hareket eden Sherman ise burada Bellmer ve Sürrealizme ait olan bir biçimi yeniden üretmiş olur. (Fotoğraf 9, 10, 12, 14) Sherman'ın bu benzerlik ve alıntılama konusunda bilinçli davrandığı, kullandığı malzeme ve konseptlerden de anlaşılabilir.

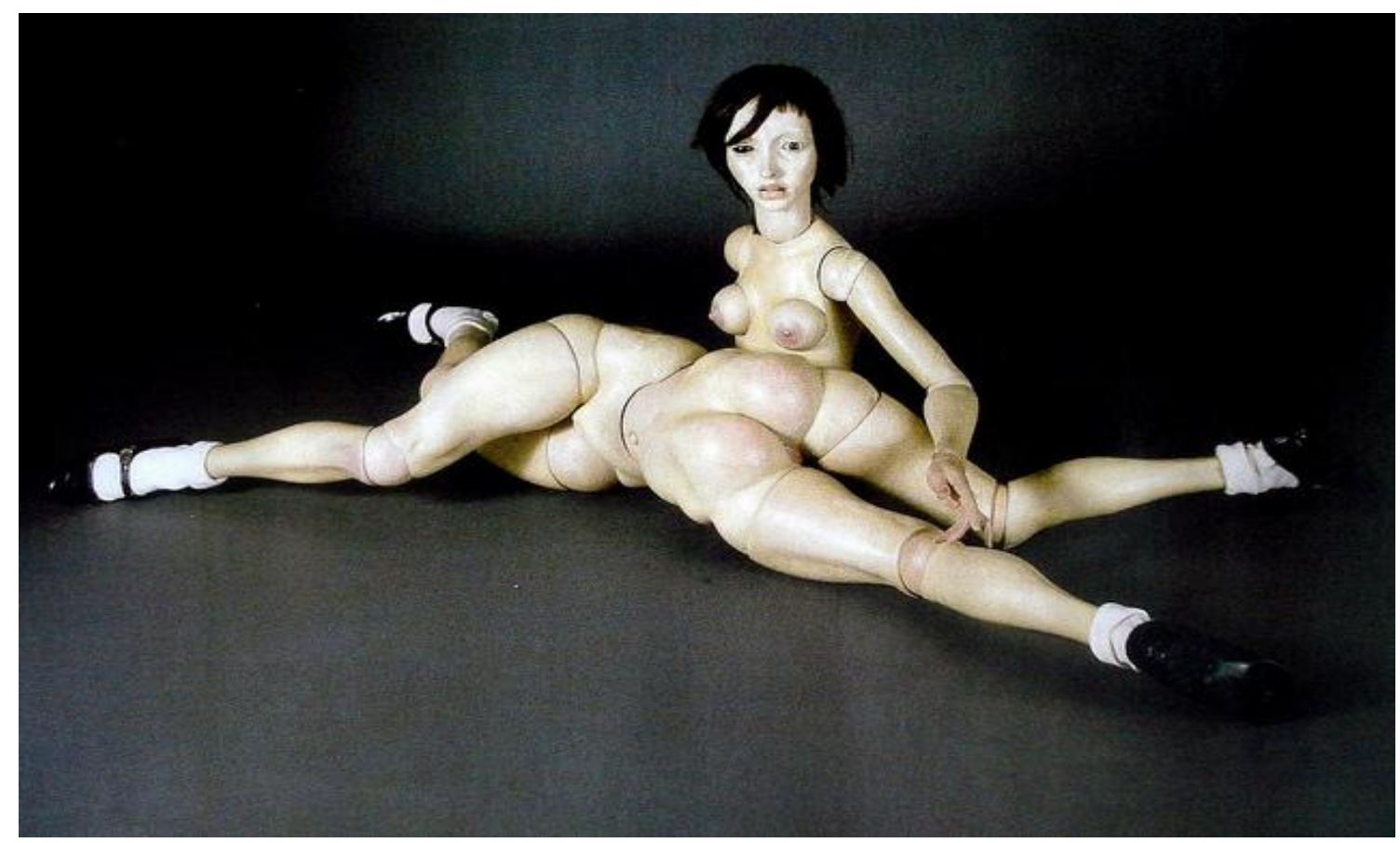

Fotoğraf 11. Hans Bellmer, 'The Doll', 1935-36, Paris

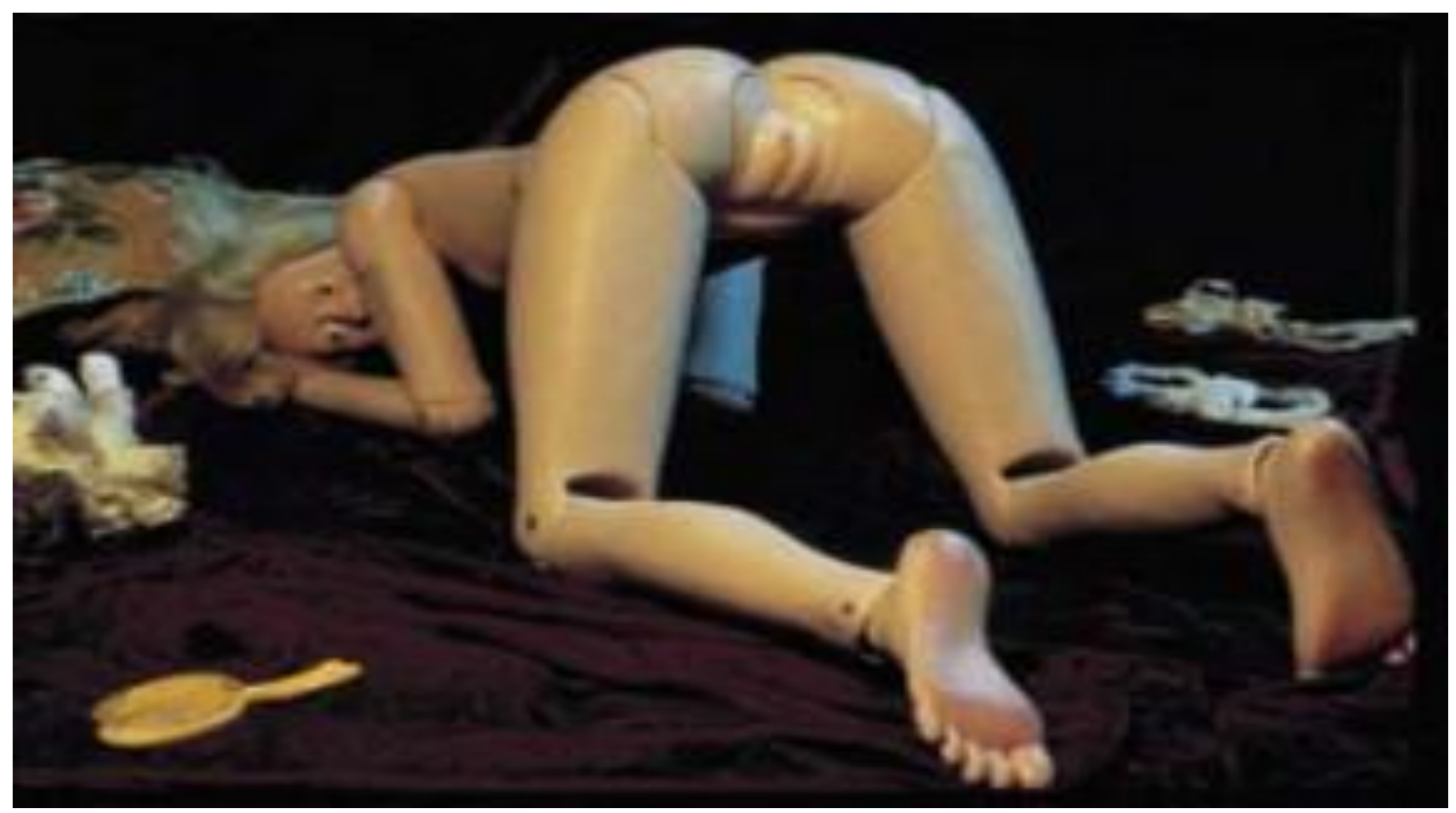

Fotoğraf 12. Cindy Sherman, 'İsimsiz 255’, 1992, MOMA 
Bellmer'in çalışmalarında görülen cinsellik ve erotizm parçalanıp birbirine eklemlenmiş bedenlerle anlatılır. Arzulanan bir nesne durumundaki beden, oyuncak bebek imgesiyle harmanlanarak seyirci ile arasına bir mesafe koyar. Cindy Sherman ise bu mesafe koyma durumunu Postmodern dönemin yabancılaştırma ve alışılagelmiş tanımlamalardan kurtarma çabası üzerinden yorumlamaya çalışır. Böylece bir kimlik karmaşası yaratılarak ezberin dışına çıkılması önerilmektedir. Sherman'ın buradaki hareket noktası yine bedendir. Gerçek ile yapay arasında kalmış bedenler cinselliği çağrıştırdığ1 gibi cinsellik ve iğrençlik arasında gidip gelirler. (Fotoğraf 12, 14)

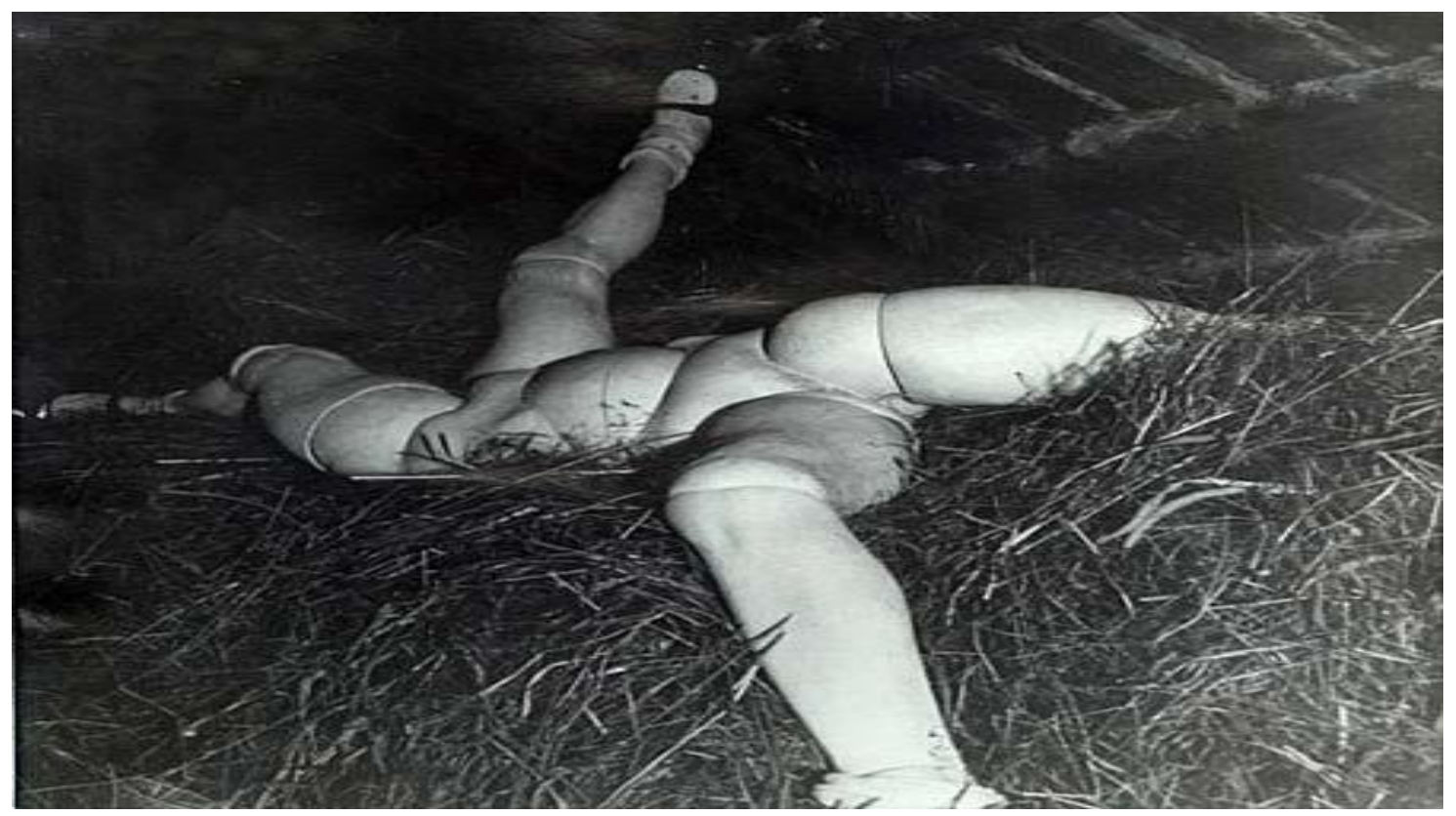

Fotoğraf 13. Hans Bellmer, 'Pre-war Photographs', 1931

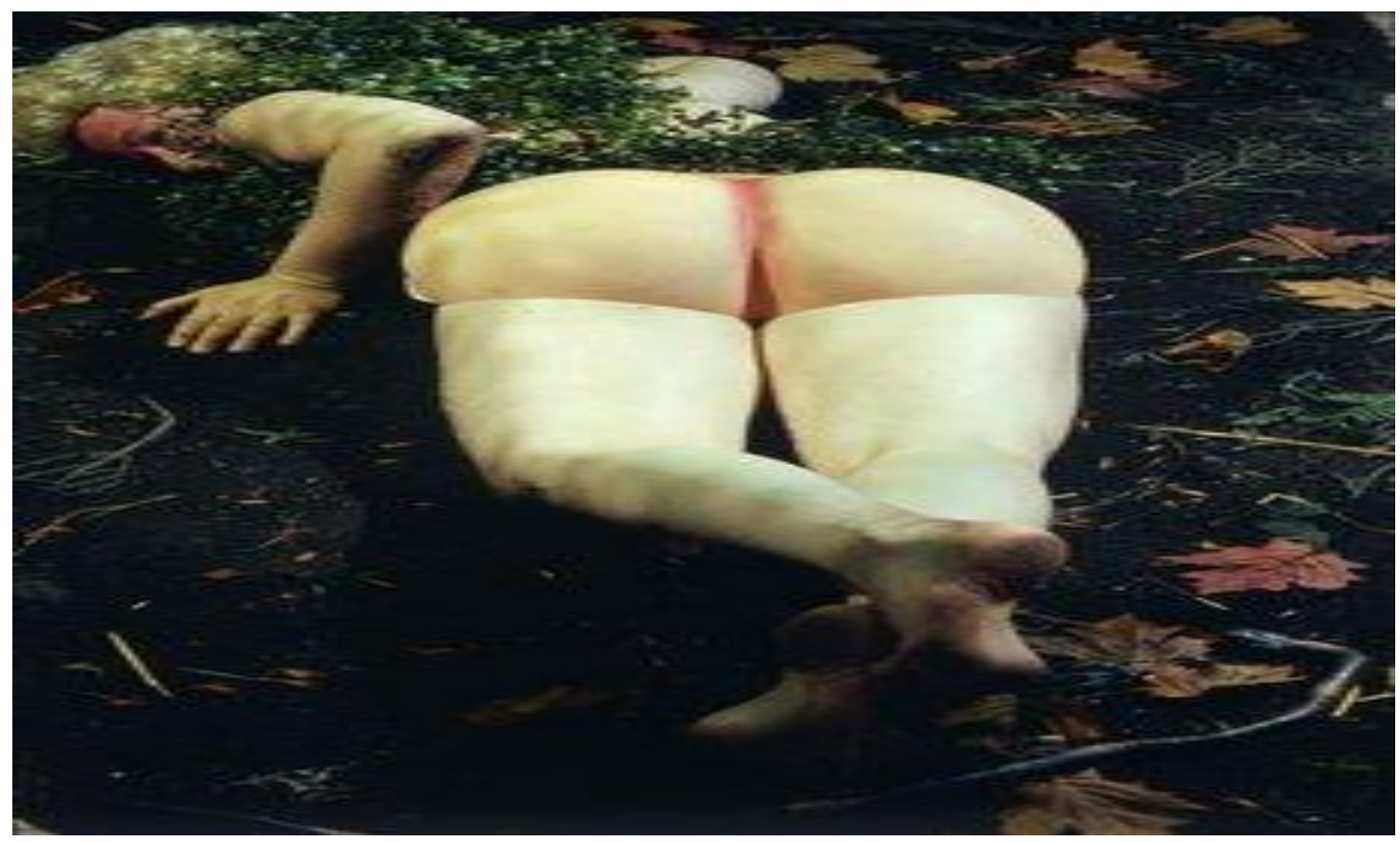

Fotoğraf 14. Cindy Sherman, 'İsimsiz 155’, 1985, MOMA 
Sherman ayrıca o yıllarda sanat tarihine mal olmuş yağlıboya resim örneklerini de yeniden canlandırmaya çalışır. (Fotoğraf 15, 16) Yağlıboya portre resminin gerçekliğini günümüzün eklektik bakış açısıyla birleştirdiğinde ortaya parçalı yapıda birbirinden kopuk kişilikler ve bedenler çıkar. Postmodern gerçeklik algısının şüpheci, rastlantısal ve çoğulcu yapisına dayanan, her an parçalanmaya hazır duruşu net bir şekilde görülebilir.

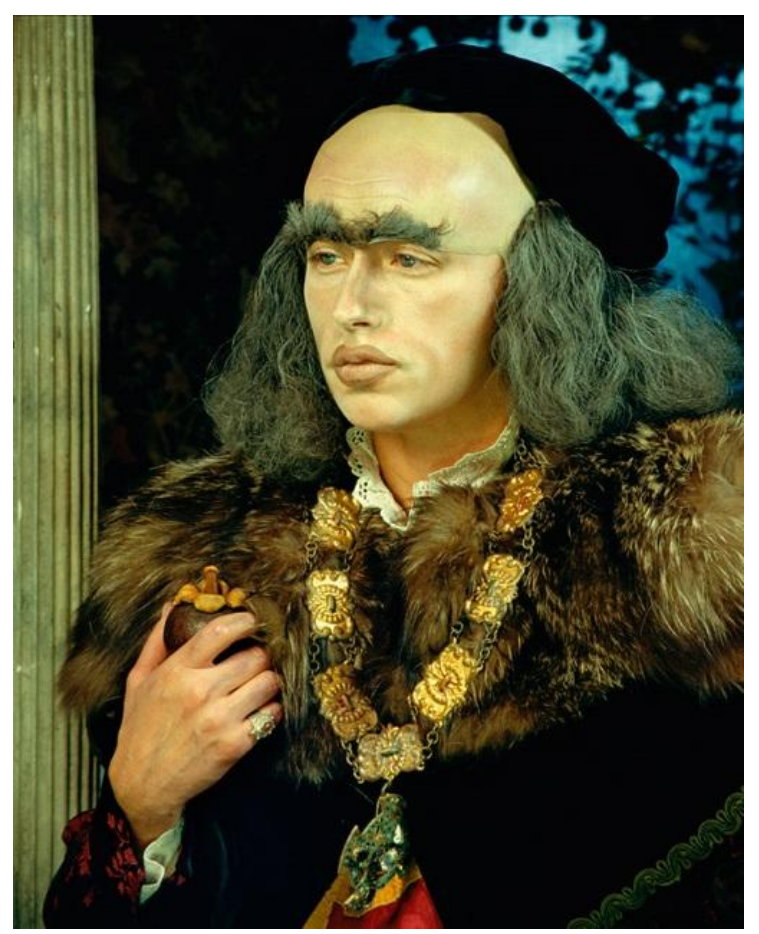

Fotoğraf 15. Cindy Sherman, 'İsimsiz 213', 1989, MOMA

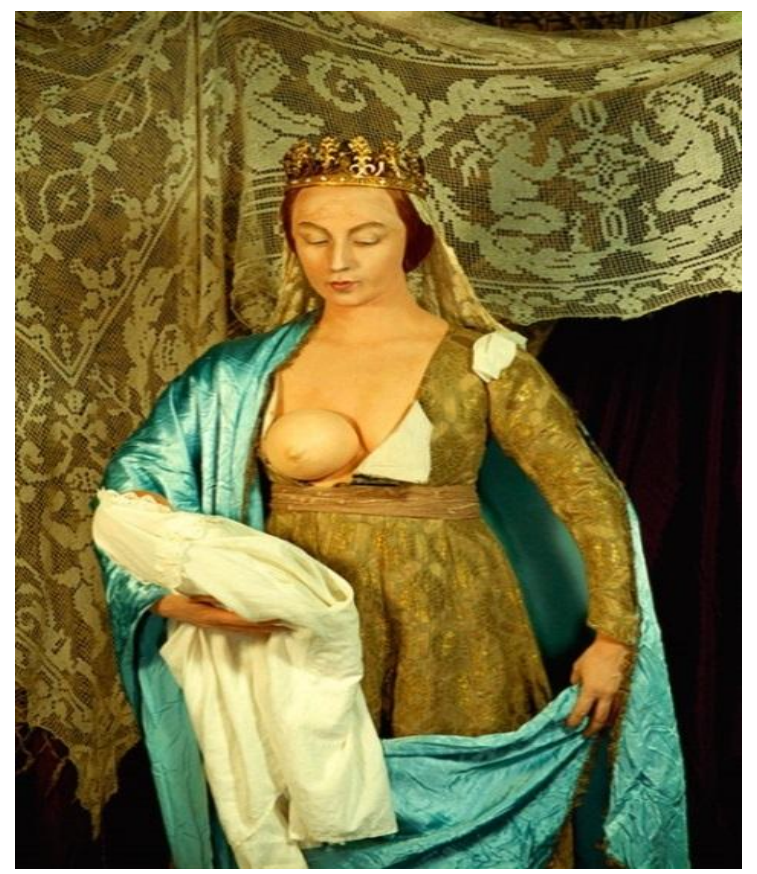

Fotoğraf 16. Cindy Sherman, 'İsimsiz 216', 1989, MOMA 
İsimsiz serilerinin 1990'lar ve 2000'lerle birlikte çift cinsiyetli kimlikler ya da birbiri içinde eriyen kimliklere dönüştüğü görülür. Sherman, sokak kültürünün topluma yansımaları, daha doğrusu sokakların gerçekliği, toplumun öteki yüzü gibi temalarla ötekileştirilmiş kimlikler üzerinde yoğunlaşır (Fotoğraf 17, 18). Kendi kendini ötekileştirmesinin yanı sıra zaten ötekileşmiş olan kimlikleri yeniden üretmiştir.

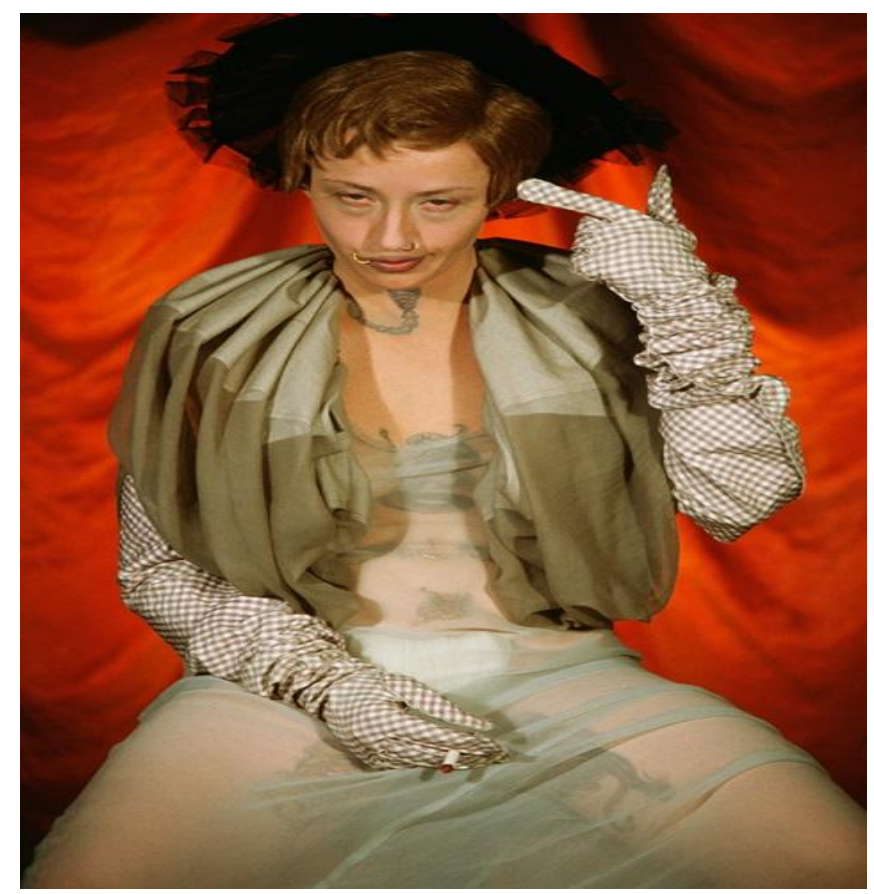

Fotoğraf 17. Cindy Sherman, 'İsimsiz 299', 1994, MOMA

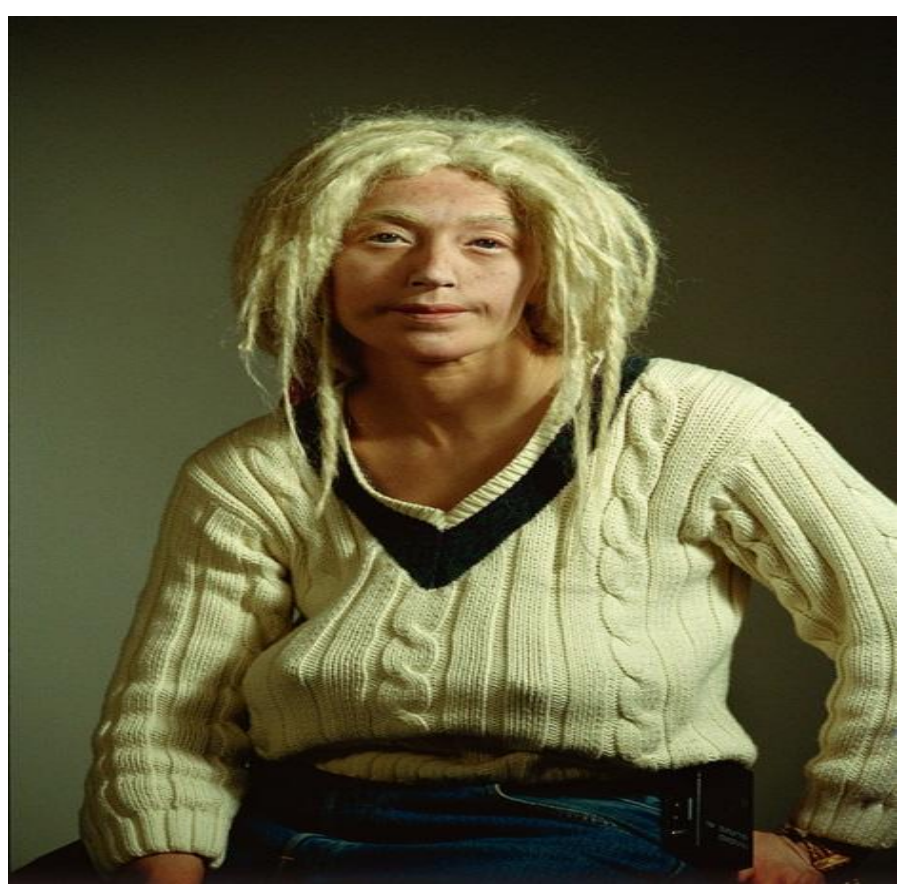

Fotoğraf 18. Cindy Sherman, 'İsimsiz 399', 2000, MOMA 
$\mathrm{Bu}$ dönem sonrasında çalışmalarında zaman ve mekan kavramının giderek belirsizleştiği görülür, ayrıca kendini giderek tanınmaz hale getirir. Önceki çalışmalarında Sherman'ın tanınmasını sağlayacak birkaç ipucu bulunurken, özellikle palyaço konulu çalışmalarında izleyici ile arasına ciddi bir mesafe koyduğu görülür. (Fotoğraf 19) Sanatçıyı tanımak imkansızdır. Kullandığı arka planlar oldukça yapay ve özneden bağımsız durur. Hollywood tiplemelerinin hem kendilerine hem de bulundukları ortama yabancılaşmış hallerini, zaman-mekan belirsizliğine başvurarak yeniden canlandırır. (Fotoğraf 20) Popülerleşmiş imgelerin sahte ve içi boşaltılmış durumları sanatçının en çok eleştirdiği durumlardandır. Gelişen teknolojinin sunduğu imkanlardan da faydalanan sanatçı özellikle photoshop programı sayesinde fotoğraflar üzerinde gereken oynamaları yapar ve onları istediği forma sokabilir.

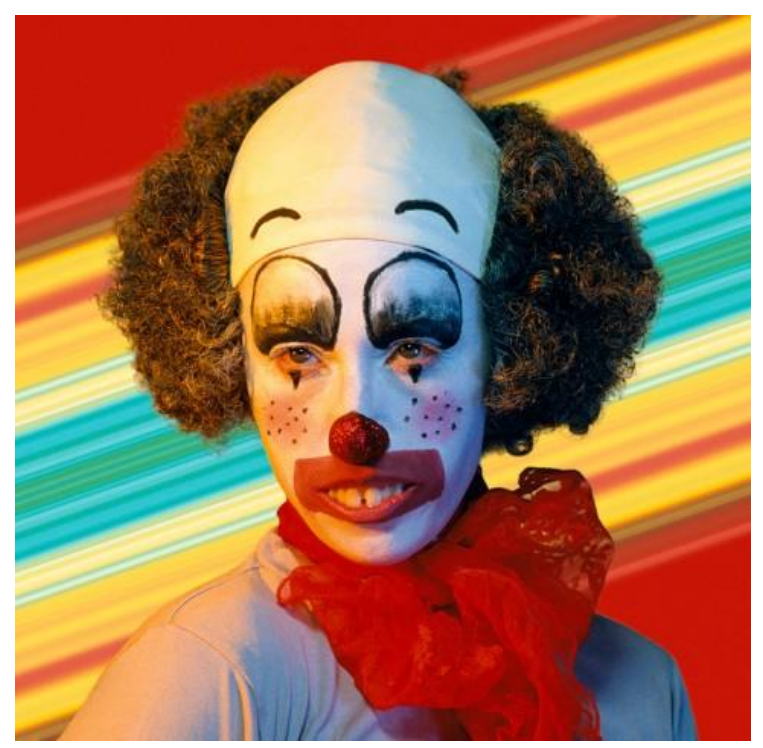

Fotoğraf 19. Cindy Sherman, 'İsimsiz 424’, 2004, MOMA

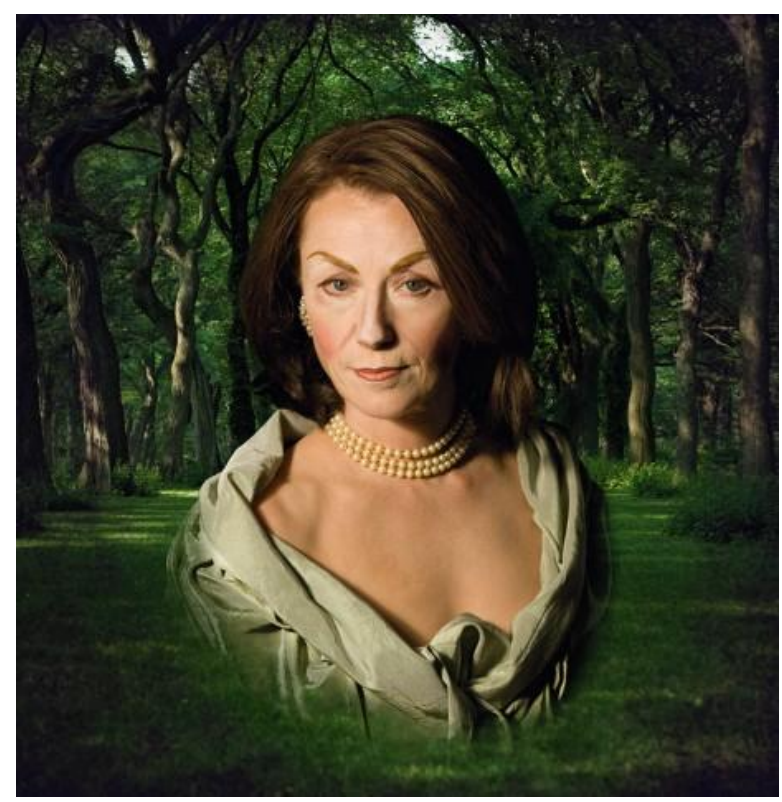

Fotoğraf 20. Cindy Sherman, 'İsimsiz 469', 2008, MOMA 
“Bu nesneler şeması içerisinde, özneyi yıpratma ve perdeyi yırtma güdüsü Sherman'ı öznenin bakışa yakalandiğı ilk çalışmalarından, öznenin bakış tarafından istila edildiği ileri dönem çalışmalarına ve de bakış tarafindan sadece parçalanmış bir oyuncă̆ı̆ parçaları olarak dönebilecek şekilde yok edildiği son dönem çalışmalarına kadar götürür. Fakat özne ve perdeye yönelik bu ikili saldırı sadece ona ait değildir; çă̆daş sanatın gerçeğin hizmetinde mücadeleye başladığı birçok cephesinde görülür." (Foster, 2009: 189) Hal Foster'ın da belirttiği gibi postmodern dönemin görme politikaları Sherman'ın fotoğraflarında tam anlamıyla yerini bulur.

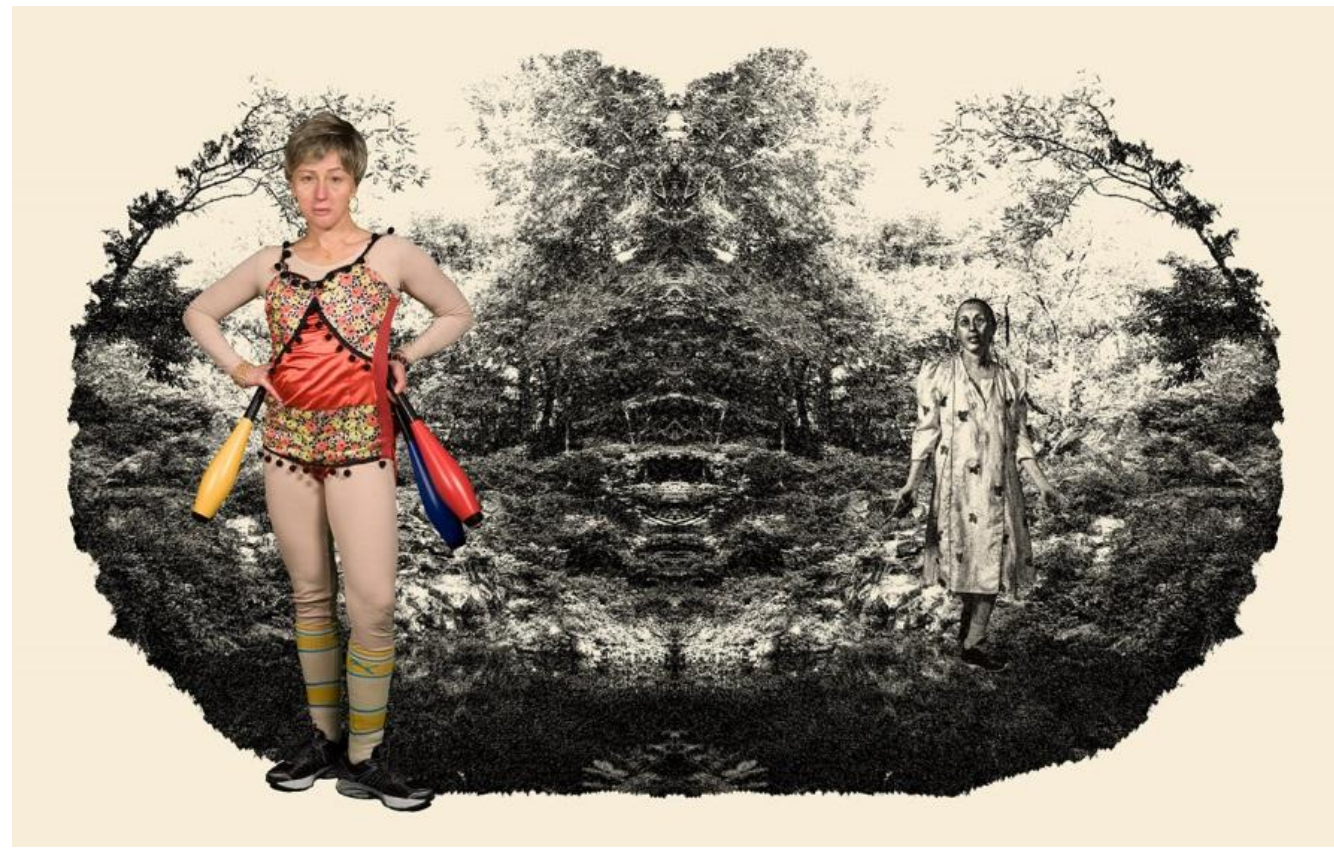

Fotoğraf 21. Cindy Sherman, 'İsimsiz', 2010-2012, MOMA

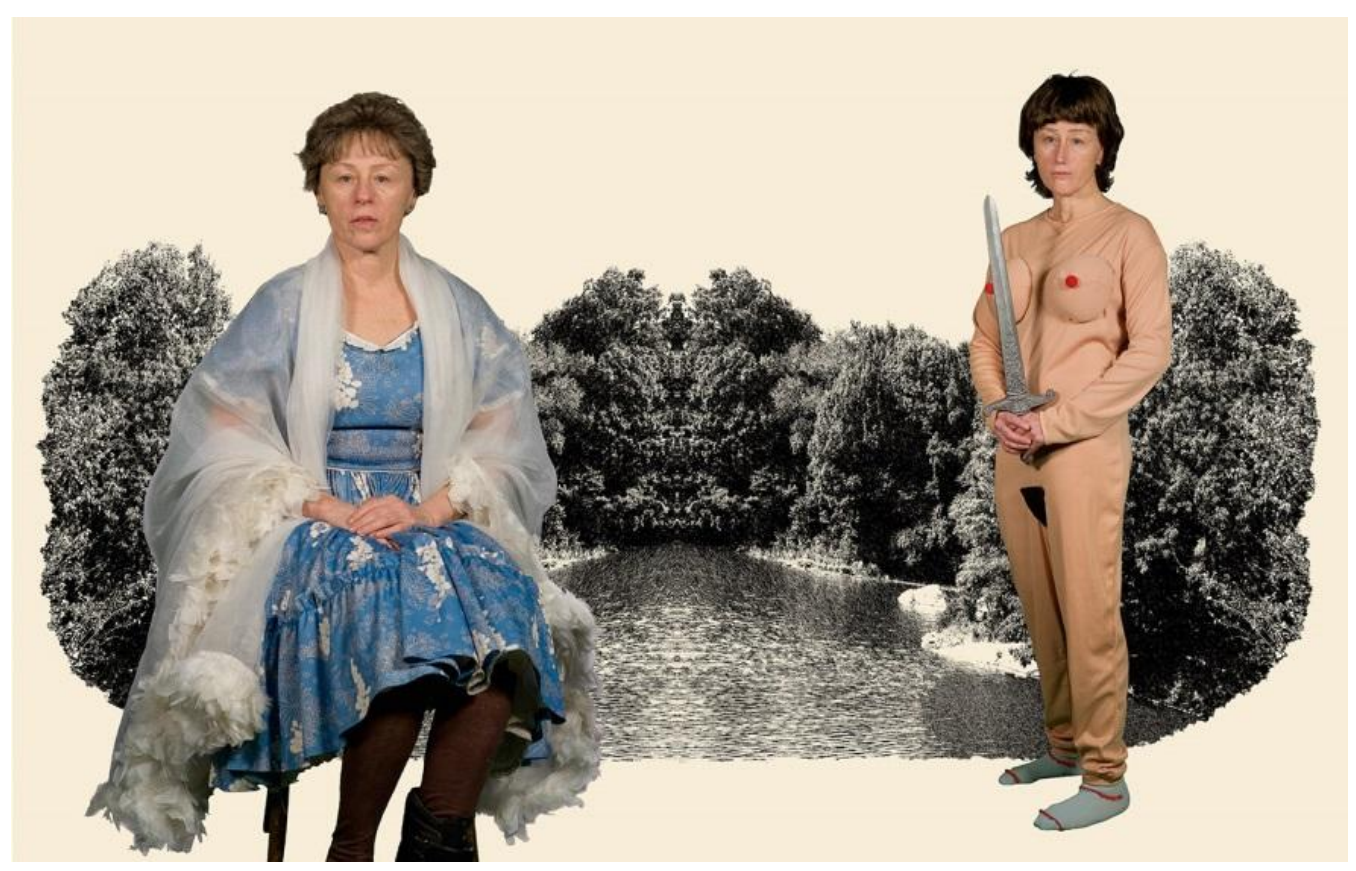

Fotoğraf 22. Cindy Sherman, 'İsimsiz', 2010-2012, MOMA 
Sanatçı 26 Haziran 2012' de New York Modern Sanatlar Müzesi'nde(MOMA) açılan sergisinde mekanın giriş kısmını boydan boya dijital fotoğraf baskılar ile kaplamıştır (Fotoğraf 21, 22, 23). 2010 ve 2012 arasında gerçekleştirdiği bu duvar kağıdı mantığındaki çalışmalarında sanatçı kendini bir şekilde anıtsallaştırır. Galeri sahiplerinin anıtsal niteliklere sahip devasa çalışmalara fırsat tanıması yeni bir uygulamadır ve MOMA'nın küratörlerinden Eva Respini de galerinin internet adresinde Sherman için açılan sayfada yer alan bir konuşmasında Cindy Sherman'ın bu çalışmalarının bir kısmını MOMA için özel olarak tasarladığını belirtir.

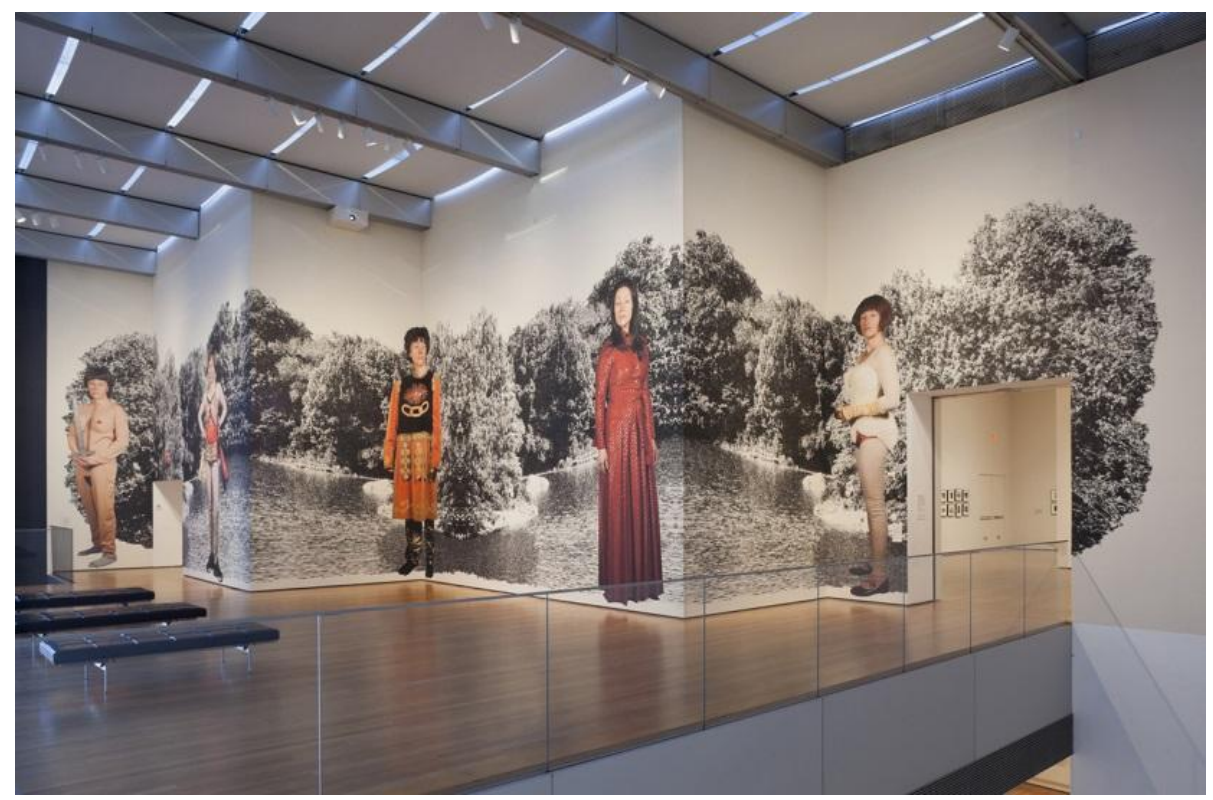

Fotoğraf 23. Cindy Sherman, 'İsimsiz', 2010-2012, MOMA

Bir retrospektif olma özelliği taşıyan sergide sanatçının bütün dönemlerini yansıtan çalışmalardan örnekler görülebilir, böylece sanatçının ne gibi değişimlerden geçtiği kolaylıkla gözlemlenir.

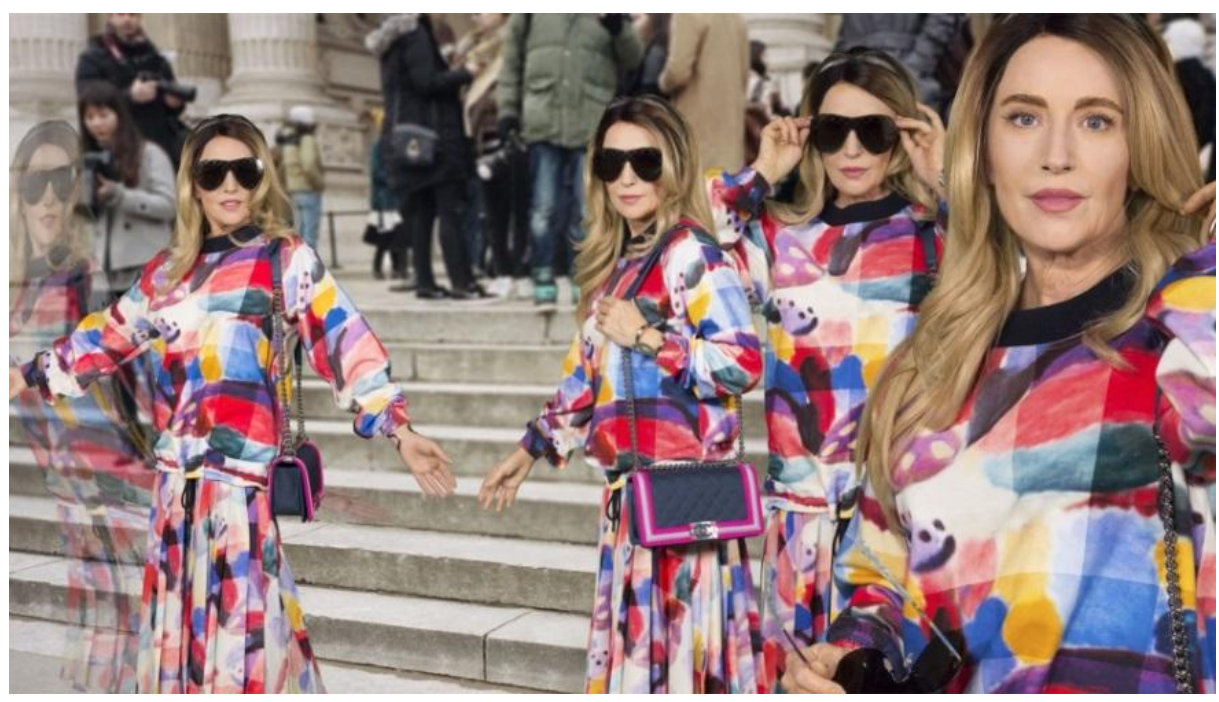

Fotoğraf 24. Cindy Sherman, 'The Art of Street Style', Harper's Bazaar Dergisi İçin Özel Çekim, 2016 


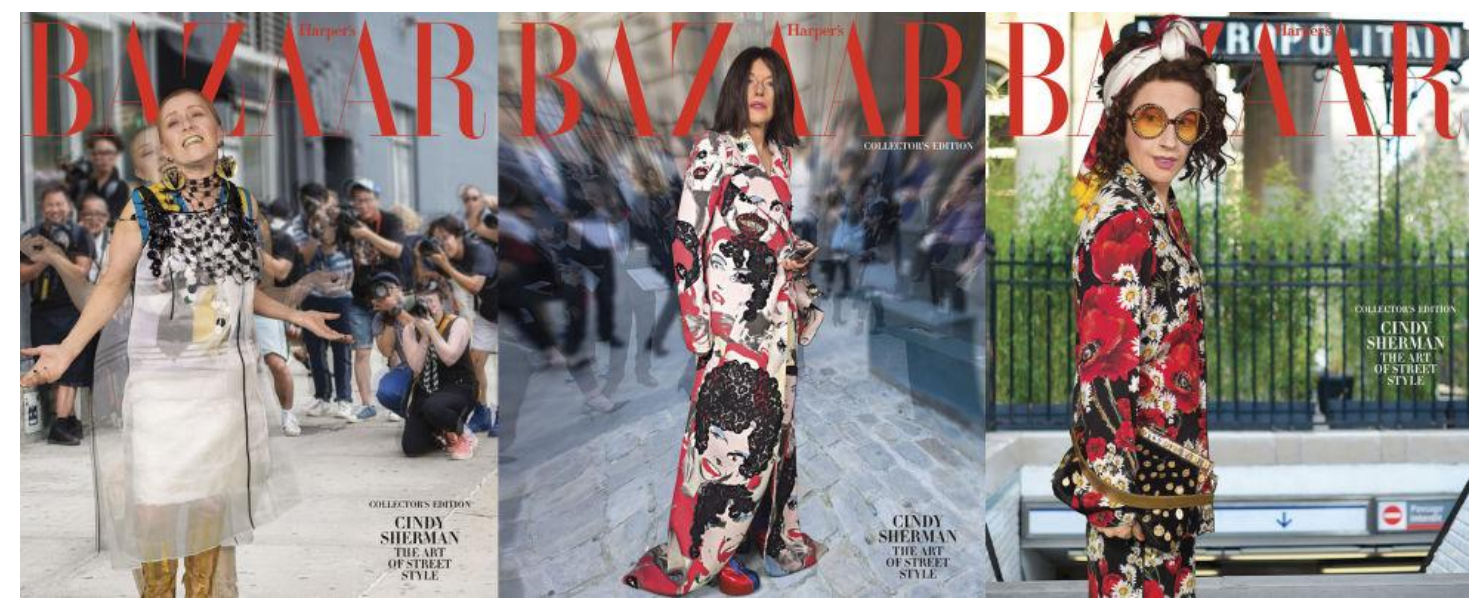

Fotoğraf 25. Cindy Sherman, 'The Art of Street Style', Harper's Bazaar Dergisi İçin Özel Çekim, 2016

Sherman'ın son dönem çalışmalarında da aynı çizgiyi devam ettirdiği görülmektedir. Sanatçının köstüm tasarliyor olması ünlü markaların uzun süredir dikkatini çekmiş ve kıyafetlerini kullanması için Sherman'a sayısız teklif gelmiştir. Bunun sonucunda Harper's Bazaar dergisi için Prada, Dolce \& Gabbana ve Chanel gibi giyim markalarının sponsorluğunda özel bir fotoğraf çekimi gerçekleştirmiştir. (Fotoğraf 24, 25) Günümüzün popüler tüketim öğelerinden biri olan moda ikonu olma durumunu hicvederek yorumlayan Sherman, 2016 sokak stilini kendine özgü yöntemlerle canlandırmaya çalışmıştır. Aynı zamanda popüler kültürle birlikte hareket eden modanın var ettiği bireyin kendini sosyal mecrada nasıl ifade ettiği konusunda da fikir edinebilmek mümkündür.

\section{SONUÇ}

Gündelik yaşamın ve tüketimin bir yansıması olarak fotoğraf, Sherman örneğinde görüldüğü gibi toplumun parçalanmış yapısını gözler önüne sermektedir. Her bir fotoğraf karesinde hem kendisine ve çevresine yabancılaşmış bir duruş hem de izleyiciye yaklaşan bir tavır söz konusudur. Bu yaklaşma durumu daha çok içinde bulunulan dönemin yaşam dinamiklerine ayak uydurma çabası olarak görülebilir. Bir sanatçı olarak Sherman'ın izlediği yöntem aslında toplum içindeki bireylerin kendi gerçekliklerinin yansıması olabilir. Sayısız özneyle dolup taşan bu sosyal çevrede belki de hepimiz farkına varmadan türlü türlü roller üstlenip farklı boyutlarda dolaşarak kendimizi var ediyoruz. 


\section{KAYNAKÇA}

Akay, A. (2002).Postmodern Görüntü. İstanbul:Bağlam Yayıncılık.

Antmen, A. (2008). Sanatçılardan Yazılar ve Açıklamalarla 20. Yüzyıl Batı Sanatında Akımlar. İstanbul: Sel Yayıncilı.

Antmen, A. (2013). Kimlikli Bedenler-Sanat, Kimlik, Cinsiyet. İstanbul: Sel Yayınc1lı.

Best, S. Kellner, D. (2011). Postmodern Teori. (M. Küçük Çev.) İstanbul: Ayrıntı Yayınları.

Baudrillard, J. (2004). Tam Ekran (B. Gülmez Çev.). İstanbul: Yapı Kredi Yayınları.

Baudrillard, J. (2008). Simülakrlar ve Simülasyon (O. Adanır Çev.). Ankara: Doğu Batı Yayınları.

Baudrillard, J. (2004). Kötülı̈̈̆ün Şeffaflı̆̆ı Aşırı Fenomenler Üzerine Bir Deneme (I. Ergüden Çev.). İstanbul: Ayrıntı Yayınları.

Baudrillard, J. (2010). Sanat Komplosu-Yeni Sanat Düzeni ve Çağdaş Estetik 1 (E. Gen-I. Ergüden Çev.). İstanbul: Ayrıntı Yayınları.

Benjamin, W. (2007) Pasajlar (A. Cemal Çev.). İstanbul: Yapı Kredi Kültür Sanat Yayıncılık.

Derman, İ. (2010). Fotoğraf ve Gerçeklik. İstanbul: Hayalbaz Kitap

Foster, H. (2009). Gerçeğin Geri Dönüşü Yüzyılın Sonunda Avangard (E. Hoşsucu Çev.). İstanbul: Ayrıntı Yayınları.

Giddens, A. (2010). Modernliğin Sonuçları (E. Kuşdil Çev.). İstanbul: Ayrıntı Yayınları.

Rigel, N. Batuş, G. Yücedoğan G. Çoban, B. (2005). Kadife Karanlık 21. YY İletişim Çă̆ını Aydınlatan Kuaramcilar. İstanbul: Su Yayınevi.

Sarup, M. (2004). Post-Yapısalcllk ve Postmodernizm (A. Güçlü Çev.). Ankara: Bilim ve Sanat Yayınları

Tekdemir Dökeroğlu, Ö. (2013) Sanatta İroni ve Öyküleme Pratikleri (Sanatta Yeterlik Eser Çalışması Raporu). Ankara: Hacettepe Üniversitesi Güzel Sanatlar Enstitüsü.

Respini, E. Cindy Sherman Sergi Tanıtımı. [Video], New York: Amerikan Modern Sanatlar Müzesi (MOMA) http://www.moma.org/explore/multimedia/videos/208 (02.12.2016)

www.cindysherman.com (30.11.2016)

www.moma.org/interactives/exhibitions/2012/cindysherman/ (02.12.2016)

http://www.harpersbazaar.com/culture/features/a14005/cindy-sherman-0316/ (05.12.2016). 